\title{
KORPUSAVUSTEINEN VIRHEANALYYSI TARKKUUDEN KEHITYKSESTÄ EVK:N TAITOTASOILLA A2-B2
}

\author{
Sisko Brunni, Oulun yliopisto \\ Jarmo Jantunen, Jyväskylän yliopisto \\ Valtteri Skantsi, Oulun yliopisto
}

\begin{abstract}
Artikkelissa tarkastellaan kielitaidon taitotasoittaista kehittymistä potentiaalisten esiintymien analyysin (Potential Occasion Analysis, Thewissen, 2015) avulla. Kehittymistä analysoidaan tarkkuuden näkökulmasta, ja sitä mitataan kohdekielen muoto- ja käyttökonventioista poikkeavien muotojen määrällä. Tutkimus on korpuspohjaista virheanalyysia (Corpus-aided Error Analysis, Dagneaux, Dennes \& Granger, 1998), ja se perustuu taitotasoilla havaittujen, yhdeksään virheluokkaan sijoittuvien virheiden määrien tilastolliseen testaukseen. Aineistona on Kansainvälinen oppijansuomen korpus (ICLFI). Analyysi osoittaa, että merkittävintä kehitys on tasojen B1 ja B2 välillä; tasojen A2 ja B1 välillä tarkkuuden kehityksessä on nähtävissä myös regressiota (esim. määrite- ja fraseologiset virheet) ja stabilaatiota, jota esiintyy erityisesti eräissä morfosyntaktisissa ja syntaktisissa virhetyypeissä. Tasojen B1 ja B2 välillä muutos on kuitenkin niin selvää, että erityisesti morfosyntaktisen ja syntaktisen tarkkuuden lisääntymisen voisi nostaa yhdeksi tasoa B2 määrittäväksi piirteeksi. Jo aiemmissa tutkimuksissa taso B1 on nähty selvänä kulminaatiopisteenä kielen kehityksessä (ks. esim. Kajander, 2013, s. 93-95; Seilonen, 2013, s. 59-61; ks. myös Thewissen, 2015), ja tämän tutkimuksen valossa näin on myös tarkkuuden kehityksessä.
\end{abstract}

Avainsanat: kielitaidon kehittyminen, korpusavusteinen virheanalyysi, potentiaalisten esiintymien analyysi, tarkkuus

Kirjoittajien yhteystiedot:

Sisko Brunni

sisko.brunni@oulu.fi

Jarmo Jantunen

jarmo.h.jantunen@jyu.fi

Valtteri Skantsi

valtteri.skantsi@oulu.fi

\section{JOHDANTO}

Tutkimuksessamme tarkastelemme, miten suomi vieraana kielenä -oppijoiden kielitaidon tarkkuus kehittyy taitotasolta ylemmälle siirryttäessä. Tutkimme 32 virheluokkaan sijoittuvia virheitä, jotka on analysoitu ICLFI-aineistosta (Jantunen, Brunni \& Oulun yliopisto, 2013). Tekstit sijoittuvat kolmelle peräkkäiselle Eurooppalaisen viitekehyksen 
(Common European Framework of Reference for Languages, CEFR, suomeksi EVK) avulla määritellylle taitotasolle: selviytyjä (A2), kynnystaso (B1) ja osaaja (B2) (Euroopan neuvosto, 2001). Aineistosta tutkitaan virheiksi luokiteltujen tapausten kvantitatiivisia ja kvalitatiivisia muutoksia potentiaalisten esiintymien analyysin (Potential Occasion Analysis, ks. Thewissen, 2015) avulla.

Potentiaalisten esiintymien analyysin lähtökohtana on suhteuttaa virheet paikkoihin, joissa virhe voisi mahdollisesti esiintyä. Menetelmä siis ottaa huomioon, ettei jonkin virhetyypin vähäinen määrä välttämättä kerro kielenpiirteen hyvästä hallinnasta, vaan se voi kertoa myös siitä, että piirrettä ei (vielä) esiinny oppijan kielessä. Analyysin mallina toimii Thewissenin (2015) tutkimus, jossa tarkasteltiin oppijoiden kielitaidon tarkkuudessa tapahtuvia muutoksia virheannotoidusta oppijanenglannin korpusaineistosta (ICLE; Granger, Dagneaux, Meunier, \& Paquot, 2009). Tutkimuksemme keskeinen kysymys on, miten virheiden määrät eri virheluokissa suhteutuvat Eurooppalaisen viitekehyksen taitotasoluokitukseen. Oletuksemme on, että virheiden määrä laskee lineaarisesti useissa virheluokissa, mutta että myös U-muotoista kehitystä, jossa virheiden määrä välillä lisääntyy, on nähtävissä. Vastaavanlaisia tendenssejä tiettyjen virhetyyppien kohdalla ovat esittäneet muun muassa Abe ja Tono (2005), Dagneaux, Dennis ja Granger (1998) sekä Thewissen (2015). Toinen kysymyksemme on, minkä taitotasojen välillä virheiden määrässä on nähtävissä tilastollisesti merkitseviä muutoksia ja millaisia ne ovat. Potentiaalisten esiintymien analyysia on hyödynnetty kahdessa oppijansuomeen keskittyvässä maisterintutkielmassa (Huttu-Hiltunen, 2017; Piri, 2017), joten menetelmää on vielä käytetty suhteellisen vähän virheannotoidun oppijansuomen korpusaineiston analysoimisessa. Tästä syystä tarkoituksenamme on myös ar- vioida analyysitavan toimivuutta oppijansuomen tarkkuuden kehityksen kuvaajana.

\section{VIRHEANALYYSISTA KORPUSAVUSTEISEEN VIRHEANALYYSIIN}

Kielenoppimisen tutkimuksessa virheiden analysointi on ollut pitkään kritiikin kohteena, koska se on nähty epätieteellisenä ja sekavana oppijankielen negatiivisiin piirteisiin keskittyvänä lähestymistapana (Ellis 2008, s. 62; Ellis \& Barkhuizen, 2005, s. 70; Granger, 2002; 2003; James, 1998). Virheanalyysia voi pitää myös formalistisena tapana lähestyä kielenoppimista, koska se on keskittynyt paljolti oppijan kohtaamiin kielioppiongelmiin (ks. mm. Ellisin [2008], Ellisin ja Barkhuizenin [2005] ja Thewissenin [2015] tutkimuskatsaukset). Jo 60- ja 70-luvuilla postuloitiin (mm. Corder, 1967; Selinker, 1972) kuitenkin oppijoiden virheiden tuottaminen luonnolliseksi osaksi kielitaidon kehittymistä ja nähtiin niiden analysoinnin myös hyödyttävän sekä oppijaa että opettajaa. (Katsaus virheanalyysiin ja sen uudempiin muotoihin Ellis, 2008, s. 45-66; Ellis \& Barkhuizen, 2005, s. 51-71; Thewissen, 2015, s. 59-99.) Virheanalyysi on fokusoinut perinteisesti nimenomaan siihen, mitä kielenoppija ei osaa, ja lisäksi useissa tutkimuksissa taustatietojen kerääminen on ollut epäsystemaattista (Virheanalyysin ongelmallisuudesta tarkemmin Long \& De Sato, 1984, s. 256-257; Van Els, Bongaerts, Extra, van Os \& Jansen-van Dieten, 1984, s. 60-67). Sittemmin etenkin korpusavusteinen tutkimus on pyrkinyt irti dekontekstualisoivasta otteesta ja tavoitellut oppijan tuotoksen holistista tarkastelua (Ellis, 2008, s. 61; Granger, 2002). Edelleen perusajatuksena on, että virheitä analysoimalla ja luokittelemalla voidaan päästä kiinni yhteen osa-alueeseen siitä, mitä oppimisessa tapahtuu ja miten oppiminen etenee. Edistysaskeleena on voitu 
pitää sitä, että virheanalyysissa keskitytään nimenomaan oppijoiden tuotoksen analyysiin toisin kuin aiemmassa kontrastiivisessa tutkimuksessa, jossa oppimista pyrittiin selittämään vertailemalla oppijan äidinkieltä ja opittavaa kohdekieltä ja ennustamaan oppimisen ongelmia tämän vertailun perusteella (ks. jo Richards, 1971). Lisäksi nimenomaan korpusavusteinen virheanalyysi on virheannotointinsa vuoksi hyvin systemaattista (Granger, 2002; ks. myös Jantunen, Brunni, Lehto \& Airaksinen, 2014).

Oppijankielen virheiden tarkastelua on perusteltu muun muassa sillä, että oppijan tekemien virheiden analysointi on tehokas tapa kuvailla oppijoiden tuottaman kielimuodon ominaispiirteitä ja kehitysvaiheita, mistä puolestaan on hyötyä toisen kielen oppimisen tutkimuksessa ja kielen opetuksessa (Brunni \& Jantunen, 2015, s. 384; Ellis, 2008: 65; Granger, 2002, s. 14; Izumi, Uchimoto \& Isahara, 2005, s. 71). Kun analyysin tutkimuskohteeksi nousi oppijan tekemien pelkkien virheiden sijasta oppijan koko L2-tuotos, havaittiin, että virheet eivät ole vain kielitaidon puutteita vaan ne ovat olennainen ja tarpeellinen osa kielen kehitystä (ks. Ellis, 2008, s. 62; Granger, 2003, s. 467). Koska oppijankieli ei ole, kuten ei ole mikään muukaan kielimuoto, täydellinen eikä vakaa järjestelmä, siihen kehittyy helposti uusia muotoja sekä ulkoisesta kieliympäristöstä että itsenäisesti ilman ulkoista ärsykettä. Tämä näkyy muun muassa tiettyjen muotojen yliedustumisena ja vakiintumattomana käyttönä sekä epäkonventionaalisuuksina (Ellis \& Barkhuizen, 2005, s. 54-55; Jantunen, 2008).

Analysoitavaa tutkimusmateriaalia on kerätty perinteisesti oppijoiden spontaanisti tuottamasta kielestä tai tiettyjen kriteerien avulla määritetystä, varta vasten kerätystä aineistosta. 1990-luvulta lähtien on käytettävissä ollut laajoja oppijankielen korpuksia (ks. CECL, 2018; myös Jantunen \& Pirkola,
2015), ja niihin pohjaava korpusavusteinen virheanalyysi (Computer-aided Error Analysis, CEA; Dagneaux ym., 1998; Thewissen, 2015) on herättänyt kiinnostusta 2000-luvun alusta lähtien (ks. tarkka kuvaus CEAtutkimuksista Thewissen, 2015, s. 59-99). Tutkimusaineistona on alettu yhä useammin käyttää virheannotoituja oppijankielen korpuksia, ja useat oppijankorpukset - kuten The International Corpus of Learner English (ICLE; Granger ym., 2009) ja Kansainvälinen oppijansuomen korpus (ICLFI; Jantunen ym., 2013) - onkin annotoitu virhetaksonomiaa hyväksi käyttäen. Korpusavusteisesta virheanalyysista on tullut laajojen aineistojen myötä merkittävä menetelmä oppijankielen ja oppimisen kehityksen tutkimuksessa (Jantunen, 2008, s. 68-69), koska menetelmän avulla pystytään paljastamaan entistä paremmin tyypilliset ja frekventit virheet ja virheryhmät sekä pureutumaan siihen, miten virheiden määrä ja laatu korreloivat kielitaidon kehittymisen kanssa (Dagneaux ym., 1998, s. 172; Thewissen, 2015, s. 124).

Virheanalyysin rinnalla on kulkenut oppijankielen kehitysvaiheiden tutkimus. Pitkään tutkimus keskittyi oletukseen, että kielitaito kehittyy tiettyjen systemaattisten vaiheiden kautta ja että toisen kielen kehitys noudattelee erityisesti kehityksen alkuvaiheessa ainakin osittain äidinkielen omaksumista (Ellis, 2008, s. 62). Tämän näkemyksen mukaan oppijoiden virheiden taustalla nähtiin paitsi lähtökielen vaikutus (interlingvaaliset virheet) myös kohdekielestä johtuvat kehitykselliset seikat (intralingvaaliset virheet), jotka ovat yleisiä kaikille kielenoppijoille lähtökielestä riippumatta. Tämä johtaa usein yliyleistämiseen, rajoitusten huomioimatta jättämiseen ja vääriin oletuksiin. Jaottelu ei ole missään nimessä selkeä, koska se, ovatko virheen taustalla kohdekielestä johtuvat seikat, kieltenvälinen vaikutus vai kenties molemmat (tai moninaiset muut kognitiiviset, yksilölliset tai 
ympäristön aiheuttamat seikat), ei ole aina yksiselitteistä (Ellis, 2008; Granger, 2003; Thewissen, 2015).

\section{TARKKUUS OSANA KIELITAIDON KEHITYSTÄ}

Oppijankielen tutkimusalan keskeinen kysymys on päästä selville, millainen kielen kehitysprosessi on, jotta oppimis- ja omaksumisprosessin kulkua voitaisiin selittää ja ennustaa. Perinteistä näkemystä kehityksestä tikapuumaisena asteelta toiselle siirtymisenä (ks. prosessoitavuusteoria Pienemann, 1998) on tämän vuosituhannen aikana haastanut näkemys kielen oppimisesta epälineaarisena, kompleksisena, ennustamattomana ja yksilöllisenä prosessina (kaaos-kompleksisuusteoriasta Larsen-Freeman 2007, 2013; Dynamic Systems Theory [DST] ja toisen kielen omaksuminen [SLA] De Bot, Lowie, \& Verspoor, 2007). Kognitiivisuuden korostamisen sijasta kielen kehitystä alettiin tutkia sosiaalisena vuorovaikutusilmiönä, ja myöhemmin myös näitä kahta yhdistävänä sosio-kognitiivisena prosessina (Dufva, Aro \& Suni, 2014, s. 21; Hulstijn ym., 2014; Larsen-Freeman, 2007). Kielen kehityksen ja sen käytön välistä kiinteä yhteyttä tukevat tutkimukset, joissa on raportoitu tarkkuuden heikentyvän siinä vaiheessa, kun kielen varioivuus lisääntyy. Tämä tukee käyttöpohjaisen näkemyksen (ks. Eskildsen, 2008; Verspoor, Schmidt \& Xu, 2012) käsitystä siitä, että ilmaukset opitaan ensin isompina kokonaisuuksina (chunks) ja vasta käytön myötä valmiita rakenteita aletaan varioida ja niiden abstraktiivisuustaso kasvaa (Kajander, 2013, s. 202; Mustonen, 2015, s. 286-297,300). Tämän näkemyksen mukaan virheiden lisääntyminen on siis osa kehitystä ja kertoo kehityksen taustalla olevista kognitiivisista prosesseista.

Oppijankieltä tutkimalla on havaittu, että vaikka kielen oppijat rakentavat kielitaitoaan askel askeleelta ja käyvät läpi tiettyjä vaiheita kielen oppimisen aikana, kehitys ei aina suinkaan etene suoraviivaisesti kohti opiskeltavan kielen natiivikäyttäjien kielen kaltaista tuotosta, vaan kehitys on voimakkaasti myös yksilöllistä ja runsaasti vaihtelua sisältävää, ja siihen voi kuulua myös taantumisvaiheita (ks. Long, 2003; Mustonen, 2015). On huomattava, että oppimisen tavoitteena ei useinkaan edes ole (abstrakti) natiivinkaltainen kielitaito, vaan tavoitteeksi voi riittää dynaaminen käyttötilanteeseen sopiva kielitaito (ks. mm. Mustonen, 2015, s. 53). Myös ylipäätään natiivin kielitaidon käyttöä vertailukohtana voidaan kyseenalaistaa. Asetelman ongelmallisuutta nimenomaan oppijankielen korpuspohjaisessa tutkimuksessa on kootusti käsitellyt Granger (2015, s. 13-16; ks. myös Mustonen 2015, s. 53, 75). Kielen oppimiselle ei nähdä varsinaista kohdekielistä päätepistettä, kuten kognitiivisessa toisen kielen oppimisen tutkimuksessa on yleensä tehty. Tavoitteena ei ole varsinaisesti ylin mahdollinen abstraktiotaso, sillä universaalia tai täysin jaettua mentaalista kielioppia ei tavata natiiveilla aikuisillakaan (Mustonen 2015, s. 53).

Ellis (2008, s. 72-111) vertailee suurta joukkoa lähinnä englanninoppijoiden tuottamaan kieleen liittyviä poikittais- ja pitkittäistutkimuksia ja vahvistaa niiden osoittavan, että L2:n kehittyminen etenee tietynlaisia samantapaisia oppimisvaiheita pitkin. Näissä vaiheissa on nähtävissä järjestys riippumatta oppijasta tai tämän äidinkielestä. Toisaalta muun muassa oppijansuomea tutkittaessa on saatu tuloksia, joiden mukaan kielen erityispiirteet (esim. suomen kielen moninainen morfofonologinen vaihtelu) vaikuttavat prosessin etenemiseen (Hammarberg, Håkansson \& Martin, 1999; Martin, 2007, s. 77). Yleisistä linjoista (esim. kielten sekoittuminen sekä semanttinen ja kieliopillinen yksinkertaisuus ovat tyypillisiä ilmiöitä kielenoppimisen alkuvaiheissa) ja oppijankielen 
yleisistä tendensseistä (Jantunen 2008; mm. kieltenvälinen vaikutus ja epäkonventionaalisuus) huolimatta oppijoilla on kuitenkin omanlaisiaan oppimispolkuja ja etenkin oppimistahti on yksilöllinen. (Oppijankielen variaatiosta ks. Ellis, 2008.) Tilastollisten analyysien ja manipulaatiotestien avulla on tarkasteltu yhtäältä lähde- ja kohdekielen sekä sosiaalisen ympäristön synnyttämää vaihtelua, toisaalta kielenkäyttäjien välillä ja yhden kielenoppijan tuotoksessa esiintyvää vaihtelua. Sinänsä vaihtelua ei ole oppijankielessä pidetty epätavallisena ilmiönä, sillä sisältäähän kieli muutoinkin luontaista vaihtelua: kieli vaihtelee esimerkiksi idiolekteittain, rekistereittäin ja alueittain. Oppijankielen variaatio on osittain sattumanvaraista, mutta siinä on merkkejä myös systemaattisuudesta: esimerkiksi tiettyjen muotojen esiintymisen todennäköisyyttä voi ennustaa sen mukaan, kuinka paljon puhujalla on aikaa suunnitella sanottavaansa ja kuka on vastaanottaja (ks. Preston, 1996; Tarone, 1983). Vaihtelua voi aiheuttaa myös kielen oppiminen toisena tai vieraana kielenä: Grangerin (2002, s. 8-9) ja Jantusen (2015) mukaan oppimiskonteksti vaikuttaa tuotoksen autenttisuuteen, koska vierasta kieltä opitaan usein kontrolloidussa ympäristössä, jossa tuotos ei ole täysin spontaania, tai koska kieltä vieraana kielenä opiskelevat eivät tyypillisesti saa samankaltaista syötöstä ympäristöstään. Kielen kehitystä leimaavasta vaihtelusta huolimatta tendenssi on kuitenkin se, että tietynlainen vaiheittaisuus on luonnollinen osa oppimisprosessia.

Tutkimuksessamme käytämme termiä kielen kehittyminen emmekä suoranaisesti ota kantaa siihen, millainen prosessi kielen kehityksen taustalla on. Perinteisesti, hieman yksinkertaistaen, on käytetty termiä oppiminen, kun puhutaan eksplisiittisestä, usein muodollisessa opetuksessa hankitusta kielitaidosta ja -tiedosta, ja omaksuminen, kun kielitaito kehittyy implisiittisesti kohde- kielisessä ympäristössä (oppimisesta ja omaksumisesta ks. Krashen, 1982, s. 10; implisiittisyydestä, eksplisiittisyydestä ja niiden yhteyksistä ks. Ellis, 2015). Tässä tutkimuksessa käytämme ensisijaisesti termiä oppiminen, koska tutkimuksemme aineisto tulee suomi vieraana kielenä -kontekstista. Näemme kuitenkin, etteivät nämä erilaiset kielen kehittymiseen liittyvät prosessit sulje toisiaan pois, joten tietyissä tapauksissa oppiminen-termi toimii myös kattoterminä molemmille prosesseille.

Tutkimuksessamme emme keskity selittämään kielen kehittymisen monimutkaista prosessia vaan tavoitteemme on selvittää, näkyykö kehityksen dynaamisuus pseudopitkittäisessä tutkimusasetelmassa, jossa tarkkuutta tarkastellaan taitotasoarvioiden perusteella ryhmitellyistä teksteistä formatiivisen virheanalyysin näkökulmasta. Tämän menetelmän mahdollisuuksiin uskovat muun muassa Gass ja Selinker (2008, s. 36-37) sekä Hasko (2013, s. 5). Myös Ellis ja Barkhuizen (2005, s. 97) pitävät asetelmaa hyvänä keinona saada selville kehityksessä tapahtuvia yleisiä trendejä. EVK:n lähtökohtana on kuvata kielen kehittymistä kommunikatiivisista lähtökohdista: taitotason edetessä kielenkäyttäjä pystyy toimimaan uusissa tilanteissa. Me pyrimme tutkimaan, voiko taitotasoasteikolla kuvatun, vaiheittaisesti etenevän kehityskulun sisään mahtua myös tiettyjen virheluokkien regressiota, joka ei kuitenkaan välttämättä ole merkki kielitaidon stabiloitumisesta vaan uudenlaisen ilmiön haltuunotosta, mikä tuottaa myös virheitä. Näkemyksemme mukaan tiettyjen virheiden lisääntyminen ei siis välttämättä kerro kielen kokonaiskehityksen regressiosta vaan se voi olla myös merkki uuden ilmiön harjoittelusta ja haltuunotosta. Siis merkki kielen oppimiseen ja omaksumiseen luontaisesti kuuluvasta dynaamisuudesta.

Aineistomme perusteella emme voi kertoa mitään yksittäisen tekstintuottajan kielitai- 
dosta ja sen kehityksestä. Lähtökohtaisesti katselemme aineistoa taitotasoarvioijien luomien raamien puitteissa. He ovat arvioineet tekstit tietyille tasoille, ja näin luoneet kehyksen, jota tarkastelemme virheanalyysin keinoin. Mielenkiintoiseksi analyysin tekee se, että arvioinnit on tehty funktionaalisesta näkökulmasta, mikä tarkoittaa, että arvioinnin ja tason valinnan lähtökohtana on viestin välittyminen. Tekstien suhde sanoman välittymiseen ja kommunikaation onnistumiseen on siis huomioitu arvioijien tekemissä taitotasoarvioinneissa, mutta omassa virheanalyysissamme emme enää sitä ota huomioon. Tekstien sisältämät epätyypillisyydet ja virheet ovat voineet toki vaikuttaa (tai olla vaikuttamatta) taitotasoarviointiin, mutta tutkimuksemme näkökulmasta olennaista on kuitenkin se, millainen kuva tarkkuuden kehityksestä tasojen välille paljastuu.

Lähde- ja kohdekielen yhteydestä kielen kehitysprosessiin on ollut aikojen kuluessa monenlaisia näkemyksiä. Varhaiset vahvaan tai heikkoon kontrastiivisen hypoteesiin (Contrastive Analysis Hypothesis) nojaavat tutkimukset korostavat L1-kielen roolia prosessissa (Ellis, 2008, s. 359-361; Lado, 1957, s. 2). Toisena ääripäänä ovat sen vastineeksi syntyneet muun muassa morfeemien oppimisjärjestystä analysoivat tutkimukset, jotka näkivät kehityksen olevan universaalia ja ensisijaisesti riippuvaista kohdekielestä (Ellis, 2008, s. 361-362). Nykyisen näkemyksen voinee tiivistää Ellisin lausumaan, jonka mukaan kaikkien kielen kehitystä käsittelevien tutkimusten on tunnustettava lähtökielen vaikutus, mutta nähtävä se paljon monimutkaisempana prosessina kuin pelkkänä virheiden lähteenä. (Ellis, 2008, s. 366, 402; Kieltenvälisen vaikutuksen kompleksisuudesta ks. Jarvis \& Pavlenko, 2008; L1-kielen vaikutuksesta oppijansuomeen ks. esim. Spoelman, 2013). Tässä tutkimuksessa tekstien tuottajia on käsitelty yhtenä ryhmänä eikä kielitaidon tarkkuuden kehitykseen liittyvää L1-kielen positiivista tai negatiivista vaikutusta (tai vaikuttamattomuutta) ole otettu huomioon (kieltenvälisestä vaikutuksesta ks. Jarvis \& Pavlenko, 2008; Odlin, 1989).

Kielitaidon kehitys on kompleksinen ilmiö, jonka kuvaaminen edellyttää useiden komponenttien havainnointia. Yksi oppimisprosessia kuvaava osatekijä on virheettömyyteen liittyvä tarkkuus, jonka rinnalle muiksi osatekijöiksi nimetään usein sujuvuus ja kompleksisuus (Ellis \& Barkhuizen, 2005; Housen \& Kuiken, 2009; Skehan \& Foster, 2008; Yuan \& Ellis, 2003). Sujuvuus liittyy kielen tuottamis- tai vastaanottamisprosessiin. Sen taustalla on muun muassa kielen automatisoituminen, reagoinnin nopeus, korjaukset, tauot sekä ilmausten idiomaattisuus ja kohdekielenomaisuus. Menetelmät keskittyvät joko kirjoituksen tai puheen nopeuden mittaamiseen tai kielen sujuvuuden ongelmista kertoviin epäröinti-ilmiöihin. Tämä voidaan toteuttaa tutkimalla esimerkiksi taukoja ja korjauksia (ks. esim. Skehan \& Foster, 2008). Kompleksisuus taas kertoo oppijan valmiudesta käyttää itselleen vaikeaa ja kykyjensä ylärajoilla olevaa, ei-automaattistunutta kieltä ja monipuolisia kielellisiä rakenteita. Ilmiö liittyy kielen useisiin tasoihin: kieltä voidaan lähestyä vuorovaikutuksen näkökulmasta, jolloin mitataan esimerkiksi käytettyjen vuorojen määrää, tai sanastollisesti tai kieliopillisesti, jolloin mittauksen kohteena ovat esimerkiksi sanamäärät, lausemäärät, lauseiden sisäiset alistus- ja rinnastussuhteet tai jonkin kieliopillisen piirteen yleisyys, esimerkiksi verbiargumenttien määrä (ks. esim. Yuan \& Ellis, 2003). Kompleksisuuden sijasta muun muassa suomalaisissa tutkimuksissa käytetään usein distribuutio-käsitettä (DEMfad-mallista Kajander, 2013; Martin, Mustonen, Reiman \& Seilonen, 2010; Mustonen, 2015). On siis selvää, että kielen kehitys on paljon muutakin kuin tarkkuuden 
kehittymistä ja että oppijankielen virheiden ja niiden kehittymisen tarkastelu antaa vain kapean kuvan ilmiöstä. Siitä huolimatta “-accuracy deserves a description as much as any other aspect of the L2 --“, kuten Thewissen (2015, s. 23) painottaa. Myös Grangerin (2003, s. 46) mukaan virheet (ja niiden kehitys) ovat erottamaton osa oppijankieltä ja siinä mielessä yhtä lailla analyysin arvoisia kuin mitkä tahansa muutkin oppijankielen piirteet tarkkuutta tarkasteltaessa.

Kielen tarkkuuden arviointi lähtee kohdekielestä, joka muodostaa tavoite- tai normimuodon, johon oppijan tuotosta verrataan: mitä lähempänä natiivien käyttämää kieltä oppijan kieli on, sitä tarkempaa se on (Housen \& Kuiken, 2009, s. 463; Martin ym., 2010, s. 60). Ongelmana tosin on määritellä, mitä natiivikielen variaatiota kulloinkin käytetään normina. Lisäksi natiivikielen määrittelyssä on otettava huomioon, että senkin voi nähdä olevan jopa yksilötasolla jatkuvassa prosessissa (ks. esim. Eskildsen, 2008: 350-352; Mustonen, 2015, s. 56). Ellis (2008) on mennyt vielä pitemmälle ja kysyy, voisiko tietyissä konteksteissa ja puhetilanteissa myös ei-natiivin kaltainen käyttö olla hyväksyttävää. ICLFI:n virhekoodauksessa ihanteellinen vertailukohde olisi korpuksen taustamuuttujien mukaan muodostettu vertailukorpus, jossa tekstit vastaisivat muodoltaan ja sisällöltään ICLFI:n tekstejä, niiden tuottajat olisivat koulutukseltaan ja asemaltaan vastaavia kuin ICLFI:ssä ja keruutilanne vastaisi aikarajoituksineen mahdollisimman pitkälti ICLFI:n tekstien keruutilannetta. Koska sellaista ei ole, toimii ICLFI:n virheiden määrittelyssä normina kirjoitettu yleiskieli.

Tarkkuuden normisidonnaisuudesta johtuen useimmat aiheeseen liittyvät tutkimukset kohdistuvat pääosin kieliopillisiin seikkoihin; niissä on tarkasteltu muun muassa virheettömien lauseiden määriä, kohdekielisten morfologisten tai sanastollisten ilmaisujen prosenttiosuuksia ja itsekorjauksia (ks. Crookes, 1989; Ellis \& Yuan, 2005). Wulffin ja Griesin (2011, s. 75-77) mukaan tarkkuus ei kuitenkaan ole vain sääntöpohjaista sanaston ja kieliopillisuuden oikeellisuutta, vaan se on mitä suurimmassa määrin kontekstiriippuvainen ilmiö; ICLFI:n virheannotointi on tehty manuaalisesti, joten siinä on voitu huomioida myös konteksti. Kontekstin huomioiminen tarkoittaa virheannotointivaiheessa sitä, että virhe koodataan yksinkertaisuuden periaatetta noudattaen kontekstin osoittamaan, todennäköisimpään virheluokkaan, ja toisaalta sitä, että kontekstia voidaan käyttää hyväksi virheen määrittämisessä. Esimerkissä (1) virhe on koodattu kontekstin perusteella loppua-verbin aikamuotovirheeksi, ja esimerkissä (2) konteksti kertoo, että kyseessä on sanajärjestysvirhe (Annotointiperiaatteista tarkemmin Jantunen ym. 2014 ja Brunni, Lehto, Jantunen \& Airaksinen, 2015). Myös virheluokkien monipuolisuus ja vaihtoehtoisten virhekoodien tarjoaminen laajentavat ICLFI:n virheannotoinnin tarkkuuden käsitettä Wulffin ja Griesin näkemyksen suuntaan.

(1) Kun työpäivä loppu <loppui>, menin ostoksille. (VI0388)

(2) Ensimmäinen katson televisiota ja sitten syön aamulla ja nukuin rannalla kuumassa auringossa. Myös minä söin hyvää ruokaa --. <Minä myös söin hyvää ruokaa --> (RU0052b) 
Yksi tapa peilata oppijankielen kehitystä on tarkastella sitä suhteessa Eurooppalaisen viitekehyksen taitotasoluokitukseen, joka pohjautuu kommunikatiivisuuteen ja plurilingvaaliseen kielenkäyttötaitoon. Koska EVK on ensisijaisesti kielitaidon kuvausjärjestelmä ja koska siinä painotetaan voimakkaasti eri kielten vertailtavuutta, ei tarkkuus ole sen tasoluokituksissa keskiössä. Tarkkuuden kehityksen tutkimuksella voisi olla kuitenkin annettavaa EVK-arvioiden tueksi: koska opiskelijoiden teksteille tehtyjen taitotasoarviointien taustalla on paljon epävarmuustekijöitä ja ne perustuvat pitkälti intuitioon, kokemukseen ja holistisiin arviointeihin ja koska arvioinnin taustalla on kriteeriviitteinen, ei esimerkiksi virheiden määrään perustuva arviointi, tulisi intuitioiden takana olevia valintoja tehdä näkyviksi (Thewissen, 2015, s. 21; arvioijien valinnoista Tarnanen, 2002).

\section{METODIT JA AINEISTO}

\subsection{Potentiaalisten esiintymien analyysi}

Korpusaineistoja käytettäessä on perinteisten virheanalyysin vaiheiden (tunnistaminen, luokittelu, kuvaaminen) lisäksi tarpeen perehtyä huolellisesti myös virheiden laskemiseen. Yleisesti käytettyjä laskentamenetelmiä ovat esimerkiksi kielenaineksen pakollisiin käyttötilanteisiin (obligatory occasion analysis) ja kielenainesten frekvensseihin (frequency analysis) liittyvät analyysit (Ellis, 2008, s. 68-69). Pakollisten käyttötilanteiden analyysissa virheettömien muotojen määrä suhteutetaan niihin paikkoihin, joissa ilmiön olisi kontekstissa esiinnyttävä (Ellis \& Barkhuizen, 2005, s. 73-92). Myös lauseen tai virkkeen (t-unit) kokoisen yksikön virheettömiin ja virheitä sisältäviin tapauksiin perustuvia, hieman eri periaatteita soveltavia laskukaavoja on käytetty ( $t$-unit -käsitteestä ks. Hunt, 1965; Thewissen, 2015, s. 48).

Potentiaalisten esiintymien analyysin (Potential Occasion Analysis, Thewissen, 2015) taustalla on ajatus, että virheet tulisi suhteuttaa paikkoihin, joissa virhe voisi mahdollisesti esiintyä. Analyysissä lasketaan kielenoppijan tekemien virheiden määrä suhteessa niiden potentiaalisiin esiintymisiin (Thewissen, 2015, s. 143-144). Analyysin laskukaavan osoittaja on kunkin virhetyypin kokonaismäärä, joka lasketaan virheannotoidusta osakorpuksesta. Suhdeluvun nimittäjänä toimiva potentiaalisten virhe-esiintymien määrä puolestaan lasketaan morfosyntaktisesti analysoidusta osakorpuksesta. Monitasoisen annotoinnin hyväksikäyttö on erityisen mielenkiintoista suomen kaltaisen morfologisesti rikkaan kielen analysoinnissa. Virheannotoinnin ja morfosyntaktisen annotoinnin lisäksi voidaan hyödyntää myös jälkimmäiseen kuuluvaa sanaluokittaista (POS) annotointia. Käsillä olevassa tutkimuksessa nimittäjät on jaettu kolmeen kategoriaan sen mukaan, onko laskentakaavassa käytetty virheiden vertailukohtana 1) lauseiden kokonaismäärää (esim. virheluokassa ylimääräinen sana), 2) saneiden kokonaismäärää (esim. fraseologiset virheet) vai 3) käyttötarkoitukseen erikseen morfosyntaktisesta osakorpuksesta määriteltyä nimittäjää (ks. myös Thewissen, 2015 , s. 144). Viimeksi mainittuja voivat olla esimerkiksi subjektien kokonaismäärä (subjektivirheet), objektien kokonaismäärä (objektivirheet) ja nominien kokonaismäärä (nominien muodostusvirheet). Suomen kielen sijamuotoja voi virheannotaation näkökulmasta tarkastella sekä käyttöön että muodostukseen liittyvinä tapauksina. Sijojen muodostukseen liittyvät virheet käsitellään ICLFI:n virheanalyysissa ensisijaisesti morfologisten virheiden luokassa ja käyttöön liittyvät tapaukset morfosyntaktisten virheiden yhteydessä.

Virheiden tunnistaminen ja luokittelu ei- 
vät myöskään ole aina yksiselitteisiä. Useissa virhetyypeissä virheellisten muotojen erotteleminen virheettömistä ja virheluokan valitseminen on selkeää ( $\mathrm{mm}$. monet morfosyntaktiset virheet suomen kielessä), mutta toisissa virhetyypeissä voi olla vaikeuksia päättää, mistä virheestä on kysymys - ja onko kyseessä lainkaan virhe. Tämä vaikeus koskee myös ICLFI:ä, jonka virheannotoinnissa ongelma on pyritty ratkaisemaan antamalla virhekoodissa virheille vaihtoehtoisia tulkintamahdollisuuksia (Brunni ym., 2015, s. 145). Milton ja Chowdhury (1994, s. 129) pitävätkin tätä tärkeänä, vaikkakin he myöhemmin toteavat, että analyysissa tuskin koskaan päästään tilanteeseen, jossa virheannotaatio kattaisi kaikki mahdolliset vaihtoehdot. Virheluokitusten systemaattisuus on ICLFI:ssä turvattu virheen kontekstin hyödyntämisellä (kontekstista tarkemmin aineiston esittelyn yhteydessä), virheanalyysien tekijöiden neuvotteluilla ja ICLFI:n virheannotointimanuaalilla, jossa kukin virheluokka on esitelty esimerkkeineen. ICLFI:n virheannotointi tehdään täysin manuaalisesti, joten tämänkaltainen jokaisen ongelmallisen kohdan erillinen tarkastelu on mahdollista (Jantunen ym., 2014, s. 74; virheiden tunnistamisen ja luokituksen ongelmallisuudesta Thewissen, 2015, s. 35-41). Tosin tämäkään menettely ei poista kaikkia eri virhekoodaajien erilaisista tulkinnoista johtuvia epäsystemaattisuuksia, joten aineiston asianmukaisuutta on pyritty lisäämään korjaamalla ja yhdenmukaistamalla virhekoodauksia vielä tutkimusvaiheessakin.

Tässä tutkimuksessa aineiston analyysissa hyödynnetään Thewissenin (2015, s. 175176) muotoilemia kehitystendenssejä: Vahvassa kehitystendenssissä virheiden määrän tilastollinen ero esiintyy vähintään yhden vierekkäisen taitotasoparin välillä (esim. B1 ja B2). Heikoksi kehitystendenssiksi luokitellaan puolestaan tapaus, jossa tilastollista eroa ei ole vierekkäisten tasojen välillä, mutta merkitsevyys on kuitenkin ei-vierekkäisten tasojen välillä (esim. A2 ja B2). Ei-kehittyvä tendenssi on puolestaan sellainen, missä tilastollisia eroja ei ole löydettävissä, vaan aineisto on tässä suhteessa homogeeninen.

\subsection{Aineisto}

Tutkimuksen aineisto on Kansainvälisestä oppijansuomen korpuksesta (ICLFI, the International Corpus of Learner Finnish, Jantunen ym., 2013), joka on noin miljoonan saneen kokoinen suomi vieraana kielenä -tekstiaineisto (tarkempi aineiston kuvaus, ks. Jantunen ym., 2014). Korpuksen tekstit on arvioitu Eurooppalaisen viitekehyksen taitotasoille A1-C2. Kuten Thewissenin (2015) tutkimusaineistossa myös ICLFI:ssä taitotasoarviointi on tehty valmiisiin tuotoksiin eikä aineistoa ole kerätty jo valmiiksi tietyille tasoille arvioiduilta oppijoilta. Arvioinnin ovat tehneet kokeneet, koulutetut EVK:n kriteeristöön perehtyneet arvioijat (taitotasojen arvioinnista ICLFI-korpuksessa ks. Jantunen, 2011; Jantunen ym., 2014; oppijansuomen korpusten taitotasoarvioinnista yleensä Jantunen \& Pirkola, 2015). ICLFI:n tekstien luokittelu on edellyttänyt vähintään kahden arvioijan samantasoisen arvion. Eurooppalaisen viitekehyksen taitotasoihin perustuvat osakorpukset on muodostettu tämän luokittelun avulla, joten saman oppijan eri tekstit voivat sijoittua myös eri tasoille. Arviot kertovat siis yksittäisen tekstin, eivät oppijan taitotason. (Ks. Jantunen, 2011.) Vaikka tekstit onkin arvioitu funktionaalisen ja kriteeriviitteisen viitekehyksen mukaan, arvioinnin taustalla oleva oppimis- ja kielikäsitys ei poista mahdollisuutta tarkastella eri taitotasoille arvioituja tekstejä juuri virheidenkin näkökulmasta. Jos tekstit olisi arvioitu taitotasoille niissä olevien virheiden perusteella, olisi arviointi itses- 
sään jo virheanalyysin ensimmäinen kierros, jonka tuotoksista tehtäisiin uusi, toisteinen virheanalyysi.

Tähän tutkimukseen on käytetty korpuksen virheannotoitua osakorpusta (A2-B2), joka on 171000 saneen kokoinen. ICLFI:n virheannotoinnissa käytetty virheluokitus perustuu virheiden kuvaamiseen eli siihen, ovatko virheet esimerkiksi sanastollisia vai syntaktisia (ks. lisää virhetyypeistä esim. Granger, 2002, s. 19). Virheiden mahdollisia aiheuttajia (esim. kieltenvälinen vaikutus tai kehitys) ei tässä vaiheessa tutkita. ICLFI:n virheluokitus on hierarkkinen ja kattaa kaikki kielen tasot fonologiasta syntaksiin, sanastoon ja fraseologiaan asti. Kaiken kaikkiaan ICLFI:n virheluokituksessa on 9 pääluokkaa: ortografiset, fonologiset, morfofonologiset, morfologiset, morfosyntaktiset, syntaktiset, leksikaaliset ja fraseologiset virheet sekä edellisiin luokkiin kuulumattomat selittämättömät virheet. Alaluokkia, joiden mukaan varsinainen virhekoodaus on tehty, on yhteensä 32. (Ks. taulukkoa 1, jossa esitellään myös pääluokkien alaluokat. Ks. myös ICLFI-virheannotointimanuaali, jossa kustakin luokasta annetaan esimerkkejä.) Esimerkiksi morfosyntaktisten virheiden alla ovat muun muassa objektin luku- ja sijavirheet. (ICLFI:n virheannotoinnista tarkemmin ks. Brunni ym., 2015; Jantunen ym., 2014).

Tarkastelumme kohteena ovat taitotasoille A2-B2 sijoittuvat virheannotoidut tekstit. Tason A2 tekstejä on 27200 sanetta, tason B1 tekstejä 88800 sanetta ja tason B2 tekstejä 54900 sanetta. Mukana ovat taitotasot A2-B2, koska aineiston määrä on kyseisillä tasoilla suurin, mikä takaa määrällisen analyysin onnistumisen. Lisäksi oppijoiden kehityksessä on näillä tasoilla huomattu tapahtuvan merkittäviä harppauksia (ks. esim. Kajander, 2013, s. 93-95; Seilonen, 2013, s. 59-61; ks. myös Thewissen, 2015). Ilmausten luokittelu virheiksi on tehty suhteessa normitettuun ja standardoituun kirjoitettuun yleiskieleen. Lähdekielinä ovat hollanti, kiina, ruotsi, tšekki sekä viro. Tekstilajit on jaettu fiktiivisiin (esim. kuvaus ja kertomus) sekä ei-fiktiivisiin (esim. arvostelu ja vastine). Aineistossa ei ole eroteltu eri lähdekielisiä tekstejä toisistaan eikä tekstilajien vaikutuksia tuloksiin ole eritelty.

Aineistomme virheannotoinnissa ja virheiden analysoimisessa nykytutkimustradition näkemys kielen sosiaalisesta luonteesta, dialogisuudesta ja tilanteisuudesta on supistunut minimiin (kielikäsityksistä ks. Mustonen, 2015). Joissakin virheluokissa konteksti on otettu huomioon (esimerkiksi sanajärjestysvirheet). Kontekstuaalisuus näkyy esimerkiksi tapauksessa, jossa oppija on kontekstin mukaan selvästi pyrkinyt kuvailemaan huonetta ja muodostanut eksistentiaalilauseen (Ikkunalla on kukka.) sijasta intransitiivilauseen (Kukka on ikkunalla.). Tällainen tapaus on merkitty virheeksi, vaikka todennäköisesti virheellinen sanajärjestys ei kommunikatiivisesta näkökulmasta vaikutakaan ilmauksen ymmärrettävyyteen. Kielen pragmaattiseen onnistumiseen liittyviä virhetyyppejä ovat muun muassa fraseologiset virheet, joissa viesti on täysin ymmärrettävä, eikä siitä voi osoittaa mitään suoranaista virhettä, mutta oppijan tuottama muoto ei ole natiivin tuottaman muodon kaltainen (natiivien kielitaidon käytöstä vertailussa ks. Mustonen, 2015, s. 52; oppijankielen korpustutkimuksessa ks. Granger, 2002, s. 12). Lähtökohtaisesti annotoinnin vertailukohde on kuitenkin norminmukainen kirjoitettu yleiskieli. Virheannotoinnissa annotoija ei ole lähtenyt arvailemaan eikä tulkitsemaan, mitä kirjoittaja mahdollisesti on tarkoittanut, vaan pitäytynyt tuotetuissa muodoissa. Tältä osin lähtökohta on hyvin pitkälti formatiivinen ja normitettu eikä pragmaattiseen onnistumiseen kiinnitetä huomiota. ICLFI:n virheannotointimanuaalissa tulkintamahdollisuudet 
on kuitenkin huomioitu ohjeistamalla aineiston käyttäjää tekemään omat rajauksensa sen mukaan kuin hän näkee parhaaksi. Aineistomme ja virhenannotointiasetelman vuoksi tutkimuksessamme kieli näyttäytyy pitkälti autonomisena ilmiönä, mikä ei kuitenkaan estä meitä näkemästä, että tämä ei todellisuudessa ole koko kuva kielestä eikä myöskään avaa kuin yhden näkökulman kielen tarkkuuden kehitykseen.

\section{ANALYYSIN TULOKSET}

Työmme analyysi rakentuu seuraavasti: Virheannotoidusta aineistosta on laskettu kullekin käsitellylle taitotasolle potentiaalisten esiintymien analyysin avulla suhdeluku, joka kertoo kunkin virheluokan virheiden ja potentiaalisten virhepaikkojen välisen suhteen. Tämän jälkeen jokaisen virhetyypin kohdalla on laskettu taitotasojen A2, B1 ja B2 välillä tapahtuvat tilastolliset muutokset Thewissenin (2015) mallin mukaan. Muutosten ja niiden perusteella tehtyjen kehityslinjojen määrittely perustuu z-testin avulla laskettuun tilastolliseen merkitsevyyteen (Sprinthall, 2011). Kaikkien kolmen taitotason välillä tapahtuvaa muutosta kuvaavat kehityslinjat on muodostettu aineistovetoisesti siten, että esiintymien suhdelukujen, z-testin tulosten sekä niiden pohjalta laskettujen p-arvojen perusteella on luotu kuvaus kehityksestä virheluokkakohtaisesti. Analyysi osoittaa, että aineistossa on kahdenlaisia tendenssejä taitotasojen välillä: 1) Vahvassa tendenssissä tilastollinen (merkitsevä tai erittäin merkitsevä) muutos on vierekkäisten taitotasojen välillä: joko taitotasojen A2 ja B1 tai B1 ja B2 välillä tai molemmissa. 2) Ei-kehittyvässä tendenssissä ei ole minkäänlaista tilastollisesti merkitsevää muutosta. Thewissenin (2015, s. 176) mallin mukaista heikkoa tendenssiä, jossa tilastollisesti merkitsevä muutos on pelkästään ei-vierekkäisten taitotasojen välillä (tässä tutkimuksessa siis A2:n ja B2:n välillä), ei puolestaan esiintynyt lainkaan tutkimusaineistossa.

Aineistosta selviää, että tasojen A2, B1 ja B2 välillä on nähtävissä neljänlaisia kehityslinjoja:

1. Yleisin eli eniten virheluokkia sisältävä kehityslinja, jossa virheiden suhteelliset osuudet vähenevät siirryttäessä alemmalta tasolta ylemmälle (kuvio 1).

2. Seuraavaksi yleisin kehityslinja on, että virheiden suhteellinen osuus lisääntyy tasojen A2 ja B1 välillä, mutta laskee siirryttäessä tasolle B2 (kuvio 2).

3. Kolmannessa kehityslinjassa virheet vähenevät siirryttäessä tasolta A2 tasolle B1, mutta lisääntyvät seuraavalle tasolle B2 siirryttäessä (kuvio 3).

4. Neljäs kehityslinja kuvaa tilannetta, jossa kehitystä ei ole tilastojen valossa nähtävissä lainkaan (kuvio 4). Tässä tapauksessa virheiden suhteellisissa osuuksissa ei siis tapahdu tilastollisesti merkitseviä muutoksia tasojen välillä.

Seuraavaksi esittelemme kunkin kehityslinjan ja annamme linjasta esimerkkejä siihen kuuluvien virhetyyppien avulla. Kaikki kolme ensimmäistä tapausta noudattavat siis Thewissenin vahvaa kehitystendenssiä, jonka mukaan tilastollisesti merkitseviä muutoksia esiintyy vierekkäisten tasojen välillä. Tieto siitä, kummassa vaiheessa (vai molemmissa vaiheissa) tilastollisesti merkitsevät muutokset tapahtuvat, on nähtävissä taulukosta 1 .

Kaikkien virheiden määrä suhteutettuna kokonaissanemäärään laskee aineistossa kielitaidon kehittyessä: virheiden osuus vähenee kielitaidon taitotasojen A2 ja B2 välillä 26,8 prosentista 14,2 prosenttiin $(\mathrm{Z}=43,969$, $p<0,001)$. Myös virheluokittaisessa tarkastelussa on vastaavanlainen virheiden vähenemisestä kertova kehityslinja yleisin (kuvio 1). 
Taulukko 1. Virheiden määrän kehitys virheluokittain. (>-merkki tarkoittaa virheiden määrän vähenemistä taitotasolta toiselle siirryttäessä, <-merkki taas virheiden määrän lisääntymistä tasolta toiselle siirryttäessä. Taulukon viimeisessä sarakkeessa on näkyvillä koko kehityslinja. $\mathrm{X}$ tarkoittaa tilastollista merkitsevyyttä.)

\begin{tabular}{|c|c|c|c|c|c|c|}
\hline \multicolumn{7}{|c|}{ VIRHEIDEN MÄÄRÄN KEHITYS } \\
\hline \multicolumn{2}{|r|}{ VIRHELUOKAT } & $A 2>B 1$ & $A 2<B 1$ & $\mathrm{~B} 1>\mathrm{B} 2$ & $\mathrm{~B} 1<\mathrm{B} 2$ & kehityslinja \\
\hline \multirow{3}{*}{$\begin{array}{c}1 \\
\text { ORTO- } \\
\text { GRAFISET }\end{array}$} & $1 \mathrm{~A}$ oikeinkirjoitus & & $x$ & $x$ & & $\mathrm{~A} 2<\mathrm{B} 1>\mathrm{B} 2$ \\
\hline & 1B välimerkit & & $x$ & $x$ & & $A 2<B 1>B 2$ \\
\hline & 1C yhdistäminen & & & $x$ & & $\mathrm{~A}_{2}<\mathrm{B} 1>\mathrm{B} 2$ \\
\hline \multirow{2}{*}{$\begin{array}{c}2 \\
\text { FONOLOGISET }\end{array}$} & 2A kvantiteetti & $x$ & & $x$ & & $\mathrm{~A} 2>\mathrm{B} 1>\mathrm{B} 2$ \\
\hline & 2B diftongi & & & $x$ & & $A 2>B 1>B 2$ \\
\hline \multirow{2}{*}{\begin{tabular}{|c|}
3 \\
MORFOFONO- \\
LOGISET \\
\end{tabular}} & $3 \mathrm{~A}$ astevaihtelu & $x$ & & $x$ & & $A 2>B 1>B 2$ \\
\hline & 3B vokaalisointu & & & $x$ & & $A 2<B 1>B 2$ \\
\hline \multirow{3}{*}{$\begin{array}{c}4 \\
\text { MORFO- } \\
\text { LOGISET }\end{array}$} & $4 \mathrm{~A}$ nominintaivutus & $x$ & & $x$ & & $A 2>B 1>B 2$ \\
\hline & 4B verbin taivutus & $x$ & & $x$ & & $A 2>B 1>B 2$ \\
\hline & $4 \mathrm{C}$ vaillinaisesti taipuvat & & & $x$ & & $A 2>B 1>B 2$ \\
\hline \multirow{8}{*}{$\begin{array}{c}5 \\
\text { MORFO- } \\
\text { SYNTAKTISET }\end{array}$} & $5 \mathrm{~A}$ viittaussuhde & $x$ & & & & $A 2>B 1>B 2$ \\
\hline & $5 \mathrm{~B}$ verbi: kongruenssivirhe muu virhe & & & $x$ & & $A 2>B 1>B 2$ \\
\hline & $5 \mathrm{C}$ subjekti & $x$ & & & & $\mathrm{~A} 2>\mathrm{B} 1>\mathrm{B} 2$ \\
\hline & 5D objekti & & & $x$ & & $A 2>B 1>B 2$ \\
\hline & 5E predikatiivi & & & & & $A 2 \approx B 1 \approx B 2$ \\
\hline & $5 \mathrm{~F}$ adverbiaali & & & $x$ & & $A 2>B 1>B 2$ \\
\hline & 5 G rektio & & & $x$ & & $A 2<B 1>B 2$ \\
\hline & 5H määrite: kongruenssivirhe muu virhe & & $x$ & $x$ & & $A 2<B 1>B 2$ \\
\hline \multirow{5}{*}{$\begin{array}{c}6 \\
\text { SYNTAKTISET }\end{array}$} & 6 A sanajärjestys & & & & & $A 2 \approx B 1 \approx B 2$ \\
\hline & 6B lauseenvastike & & & & & $A 2 \approx B 1 \approx B 2$ \\
\hline & $6 \mathrm{C}$ lauseke & & & $x$ & & $\mathrm{~A} 2<\mathrm{B} 1>\mathrm{B} 2$ \\
\hline & 6D lausetyyppi & & & & & $\mathrm{A} 2 \approx \mathrm{B} 1 \approx \mathrm{B} 2$ \\
\hline & 6E ylimääräinen sana & & $x$ & $x$ & & $A 2<B 1>B 2$ \\
\hline \multirow{7}{*}{$\begin{array}{c}7 \\
\text { LEKSI- } \\
\text { KAALISET }\end{array}$} & 7A nominin muodostus & $x$ & & $x$ & & $A 2>B 1>B 2$ \\
\hline & 7B verbin muodostus & $x$ & & & & $A 2>B 1<B 2$ \\
\hline & 7C sananvalinta & $x$ & & $x$ & & $A 2>B 1>B 2$ \\
\hline & 7D uudismuodoste & $x$ & & & & $A 2>B 1>B 2$ \\
\hline & 7E tyyli ja rekisteri & & & & $x$ & $A 2>B 1<B 2$ \\
\hline & $7 \mathrm{~F}$ vierassana & $x$ & & $x$ & & $A 2>B 1>B 2$ \\
\hline & 7G sana puuttuu & & & $x$ & & $A 2>B 1>B 2$ \\
\hline 8 FRASEOLOGISET & fraseologia & & $x$ & $x$ & & $A 2<B 1>B 2$ \\
\hline 9 SELITTÄMÄTTÖMÄT & selittämätön & & & $x$ & & $A 2>B 1>B 2$ \\
\hline
\end{tabular}




\section{1. $\mathrm{A} 2>\mathrm{B} 1>\mathrm{B} 2$}

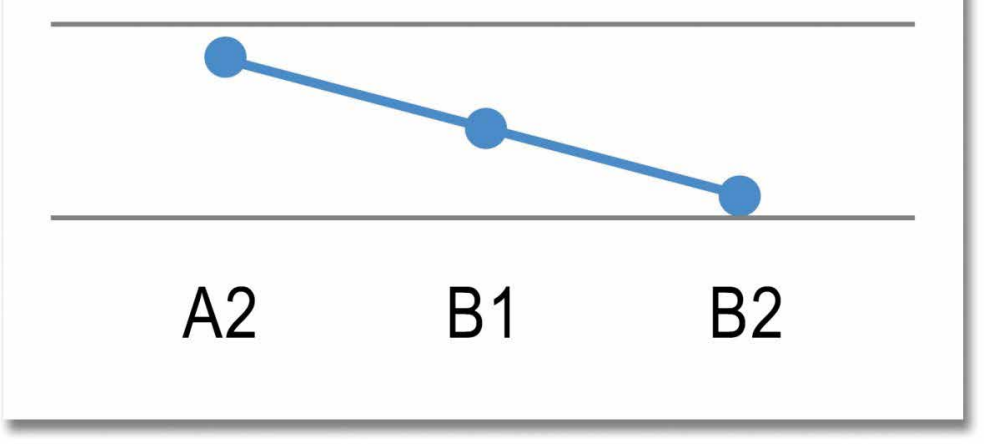

Kuvio 1. Virheiden määrän muutos taitotasojen A2, B1 ja B2 välillä: kehityslinja 1.

Tämä kehityslinja siis kertoo, että virheiden määrä suhteessa potentiaalisiin virhepaikkoihin vähenee taitotason noustessa; mukana ovat myös tapaukset, joissa ainakin toisessa tasojen välisessä vaiheessa on suhteellista vähenemistä, vaikka muutos ei välttämättä olekaan tilastollisesti merkitsevä. Tähän kehityslinjaan vaikuttaa epäilemättä myös pseudopitkittäistutkimuksellinen tutkimusasetelma. Arvioijat ovat luokitelleet tekstit taitotasoille, ja voidaan epäillä, että tasojen määrittelyssä on voinut olla yhtenä tekijänä vaikuttamassa myös tekstien virheellisyys, vaikka varsinainen EVK:n avulla tapahtuva tasojen luokittelu perustuukin yleensä kommunikatiivisten kriteerien käyttöön (EVK, 2003, s. 244).

Tilastollisesti merkitsevää virheiden lineaarista vähenemistä tasojen A2 ja B2 välillä tapahtuu kaikkiaan kuudessatoista virheluokassa (taulukko 1). Virheiden määrä vähenee tasaisesti ja tilastollisesti merkitsevästi erityisesti useimmissa morfologisissa, morfosyntaktisissa ja leksikaalisissa luokissa. Näihin virheluokkiin kuuluvat muun muassa keskeiset suomen kielen morfosyntaktiset piirteet, joita oppija oletettavasti käyttää ja harjoittelee heti kielen omaksumisen alkuvaiheessa. ${ }^{1}$ Tällaisia ovat esimerkiksi objektin ja subjektin sija- ja lukuvalinta sekä nominin ja verbin taivutus (3 ja 4). Myös sananvalinnassa ja nominien muodostamisessa ( 5 ja 6 ) virhemäärien suhteelliset osuudet laskevat tasaisesti. Tästä kehityslinjasta voidaan erottaa kolme erilaista tapausta, jotka kertovat virheiden määrän kehityksestä: 1) tilastollinen muutos sekä tasojen $\mathrm{A} 2$ ja B1 että tasojen B1 ja B2 välillä $(\underline{\mathrm{A} 2>\mathrm{B} 1>\mathrm{B} 2}), 2)$ muutos vain tasojen A2 ja B1 välillä $(\underline{\mathrm{A} 2>\mathrm{B} 1}>\mathrm{B} 2)$ ja 3$)$ muutos vain tasojen $\mathrm{B} 1$ ja B2 välillä $(\mathrm{A} 2>\underline{\mathrm{B} 1>\mathrm{B} 2})$.

\footnotetext{
${ }^{1}$ Aikuisille suunnatuissa oppikirjoissa ja oppikirjasarjoissa (esim. Gehring \& Heinzmann, 2010; 2012; Gehring, Heinzmann, Päivärinne \& Udd, 2013; 2016; Kenttälä, 2006; 2012; Tikkanen \& Tähtinen, 2017; 2018; White 2003;) tekstissä mainittuja seikkoja on formatiivista kielitaidon kehityskäsitystä noudattaen käsitelty sarjan tai kirjan alkuvaiheessa. Opetuksessa (ja myös opiskelijan omassa toiminnassa) on toki voitu noudattaa myös funktionaalista periaatetta, jonka mukaan etenemisjärjestys riippuu oppijoiden tarpeista, mutta koska mm. verbien taivutus, kieliopilliset sijat ja monikäyttöiset lausetyypit ovat frekvenssinsä puolesta hyvin yleisiä, voi mainittujen muotojen ja rakenteiden olettaa tulevan esille myös näissä tapauksissa jo oppimispolun alkupuolella.
} 
(3) nominin taivutus: --14,76 hehtaarta <hehtaaria >--. (VE0087c)

(4) verbin taivutus: -- minä katsoan <katson>--. (RU0004f)

(5) sananvalinta: Mä kävelin ja sekin oli kiva, vaikka paljon märkää lunta kaatui. (RU0059a)

(6) nominin muodostus: Suomalaisessa almanahassa <almanakassa> ovat suomalaiset nimiasut. (VI0423)

Ensimmäisessä tapauksessa muutos on tilastollisesti merkitsevä sekä tasojen A2 ja B1 että tasojen B1 ja B2 välillä (A2>B1>B2). Näin on seitsemässä virheluokassa, jotka ovat fonologinen kvantiteettivirhe, morfofonologinen astevaihtelu, leksikaaliset nominien muodostus-, sananvalinta- ja vierassanavirheet (7) sekä morfologiset nominin- ja verbintaivutusvirheet (taulukko 1). Suurin muutos suhdeluvuissa on nominintaivutuksessa, jossa virheiden osuus laskee 5,6 prosentista (A2) 3,0 prosenttiin (B1) ja siitä taas 1,8 prosenttiin (B2) (A2>B1: $Z=12,765, p<0,001$; $\mathrm{B} 1>\mathrm{B} 2: \mathrm{Z}=9,090, p<0,001)$. Suomen kielen rikas taivutusjärjestelmä aiheuttaa virheitä kaikilla tasoilla, mutta tuloksista kuitenkin selviää, että nominitaivutuksessa virheiden suhteellinen osuus vähenee tasaisesti siirryttäessä taitotasolta seuraavalle. Tähän virheluokkaan on laskettu vain tapaukset, joissa virheet voi paikallistaa nominitaivutukseen (8). Sijamuoto on siis oikea, mutta taivutuksessa on ongelmia joko taivutusvartalon tai sijapäätteen variantin valinnassa. Tähän eivät siis kuulu nominin muodostamiseen (virhe vartalossa) tai nominin morfosyntaktiseen käyttöön (väärä sijamuoto) liittyvät ongelmat (9 ja 10).

(7) 8 dec Minä heräsin kello yhdeksän. (RU0046)

(8) Kokkaan harvoin siksi minulla ei ole astianpesukonea <astianpesukonetta>. (VI0358)

(9) Hän itse soittaa bassaa <bassoa $>$. (TS0037b)

(10) Ja Punahilkka alki poimi kukka <kukkia> mummolle. (TS0027d)

Aineiston mukaan myös nominin muodostamiseen (9) liittyvät ongelmat vähenevät tasaisesti taitotasojen välillä $(\mathrm{A} 2>\mathrm{B} 1: \mathrm{Z}=6,138$, $p<0,001 ; \mathrm{B} 1>\mathrm{B} 2: \mathrm{Z}=7,755, p<0,001)$, mikä myös osaltaan kertoo nominien hallinnassa havaittavasta tarkkuuden kehityksestä taitotasojen välillä. Edelliset virheluokat (nominitaivutus ja nominien muodostaminen) siis kertovat, että nominien muotoon liittyvissä luokissa tarkkuus kehittyy tasaisesti. Nominien morfosyntaktiseen käyttöön (sijavalinta) liittyvää tarkkuuden kehitystä kuvaavat virheet, jotka jakautuvat useisiin luokkiin (mm. subjekti-, objekti-, predikatiivi- ja adverbiaalivirheet), noudattavat predikatiivi- virheitä lukuun ottamatta kehityslinjaa 1 . Näissä luokissa väheneminen ei ole tilastollisesti merkitsevää molemmissa taitekohdissa vaan esimerkiksi subjektin tarkkuus kehittyy erityisesti tasojen A2 ja B1 välillä, kun taas objektin ja adverbiaalin kehitys on tilastollisesti merkitsevää vasta tasojen B1 ja B2 välillä (taulukko 1). Edellä kuvattu kehitys antaa viitteitä siitä, että nominien muodostus tarkentuu aikaisemmin kuin niiden morfosyntaktinen käyttö. Kvantiteetti-, astevaihtelu- ja vierassanavirheissä tarkkuuden lisääntyminen kertonee harjoittelun ja opiskelun myötä tapahtuvasta kirjoitustaidon vakiintumisesta. Kaikissa näissä tapauksissa kehitys liittyy lähinnä 
virheluokan sisäisiin määrällisiin muutoksiin.

Kuten edellä jo kävi ilmi, useissa kehityslinjan 1 tapauksissa tilastollisesti merkitsevää tarkkuuden kehitystä ei tapahdu molemmissa taitotasojen taitekohdissa. Pelkästään tasojen A2 ja B1 välillä tapahtuvaa kehitystä $(\underline{\mathrm{A} 2}>\mathrm{B} 1>\mathrm{B} 2)$ on havaittavissa vain kolmessa virheluokassa: possessiivisuffikseissa, subjektin morfosyntaktisessa käytössä ja uudismuodosteissa (11), joissa virheiden kokonaismäärä on kuitenkin niin pieni, ettei sen perusteella voi tehdä johtopäätöksiä kehityksestä. Possessiivisuffikseissa tapahtuu kaikkein suurin muutos kolmen tutkitun tason välisessä kokonaiskehityksessä (A2>B2: $\mathrm{Z}=8,136$, $p<0,001)$. Muutos tapahtuu ensisijaisesti tasojen A2 ja B1 välillä: tason A2 virheprosentti 43,6 laskee B1-tason 29,7 prosenttiin, eikä osuus sanottavammin muutu enää tasolle B2 tultaessa. (A2>B1: $\mathrm{Z}=8,865, p<0,001$, $\mathrm{B} 1>\mathrm{B} 2: \mathrm{Z}=0,013, p<0,10)$. Tämä selittyy sillä, että tasolla $A 2$ luokan virheet ovat pääsääntöisesti seurausta possessiivisuffiksin puuttumisesta, mikä puolestaan kertonee siitä, että ilmiötä ei yleensä systemaattisesti opeteta eikä oleteta hallittavan vielä suomen kielen opiskelun alkuvaiheessa (12). Seuraavilla tasoilla B1 ja B2 possessiivisuffikseja alkaa ilmaantua kieleen, vaikka niiden käyttö ei olekaan vielä täysin vakiintunutta (13). Molemmilla tasoilla possessiivisuffikseja myös edelleen puuttuu (14), kuten A2-tasollakin (12).

(11) Suurin työkannattavaisuus minulla on lopussa. (TS0002i)

(12) A2: Minun isoisä <isoisäni> rakenti sen --- (VI0308)

(13) B1: Siskon nimeni <siskoni nimi> on Juta. (VI0429b)

(14) B2: Hänen töiden < töidensä > sininen värivivahde --- (VI0416c)

Myös subjektin morfosyntaktisessa hallinnassa tapahtuva muutos sijoittuu juuri tasojen A2 ja B1 välille $(Z=4,1756, p<0,001)$. Tämä selittynee sillä, että kielen käytössä frekvenssiltään yleisen subjektin harjoittelu on keskeistä kielen opiskelun alkuvaiheessa, ja sen oletetaan olevan hallinnassa jo tasolla B1. Toisaalta tietyissä erikoislausetyypeissä (eksistentiaalilause, omistuslause, genetiivialkuinen lause) tasolla $\mathrm{A} 2$ on vielä paljon subjektin sijavalintaan liittyviä virheitä (15, 16 ja 17).

(15) A2: Tsekissa ei ole meri < merta $>$. (TS0017h)

(16) A2: Minulla ei ole sauna <saunaa>. (VI0286a)

(17) A2: Jos he <heidän> täytyy mennä koulun, he enää eivät ole iloiset. (VI0421)

Myös kolmannessa kehityslinjan 1 alle kuluvassa tapauksessa tarkkuus lisääntyy siirryttäessä tasolta toiselle, mutta tilastollisesti merkitsevät muutokset sijoittuvat tasojen B1 ja $\mathrm{B} 2$ välille $(\mathrm{A} 2>\underline{\mathrm{B} 1>\mathrm{B} 2})$. Tähän ryhmään kuuluvia virheluokkia ovat diftongin muo- dostamiseen (18), vaillinaisesti taipuvien sanojen morfologiaan (19) sekä morfosyntaktiset objektiin (20), adverbiaaleihin (21) ja verbin kongruenssiin (22) sekä sanan puuttumiseen (23) liittyvät virheet (taulukko 1). 
(18) kello pouli < puoli > yksi (VI0225d)

(19) minä melkäin < melkein > nukahdin (RU0041a) ${ }^{2}$

(20) Minä soita piano < pianoa $>$ (RU0005g)

(21) Minä jään Uumajassa < Uumajaan>. (RU0050c)

(22) Minä soita <soitan> piano. (RU0005g)

(23) Luen kirjan sain joululahjassa. > Luen kirjan, <jonka> sain joululahjassa. (RU0054c)

${ }^{2}$ Vaihtoehtoisena virhekoodina on fonologinen diftongivirhe.

Suomen kielen objektin sija- ja lukuvaihtelua pidetään yleisesti vaikeasti haltuun otettavana piirteenä (Elo, 2000; Martin, 2002; Muikku-Werner, 2002; Spoelman, 2013), ja näin näyttää olevan myös tämän tutkimuksen perusteella. Esimerkiksi objektin hallinnassa tapahtuu selvää kehitystä kautta linjan: prosenttiosuudet laskevat A2:n 24,8 prosentista B1-tason 22,1 prosenttiin ja B2-tasolla 11,5 prosenttiin, mutta tilastollisesti merkitsevää kehitys on vasta tasojen $\mathrm{B} 1 \mathrm{ja} \mathrm{B} 2$ välillä. $(\mathrm{A} 2>\mathrm{B} 1: \mathrm{Z}=2,327,0,01<p>0,05 ; \mathrm{B} 1>\mathrm{B} 2$ : $\mathrm{Z}=12,521, p<0,001)$. Objektin morfosyntaktiset virheet ovatkin luokka, jossa prosentuaalinen kokonaismuutos tasojen A2 ja B2 välillä on kaikkein suurin (A2>B2: Z=13,10, $p<0,001)$.

Vaikka tilastollinen analyysi kertookin virheiden vähenevän ja tarkkuuden kehittyvän taitotasojen noustessa, on kuitenkin muistettava, että virheluokkien sisällä voi edelleen olla monenlaisia virheitä ja niiden kehitys ei välttämättä ole tasaista. Tämä selviää Pirin (2017) samalla metodilla ja samasta aineistosta tekemästä objektin morfosyntaktisia virheitä tarkastelevasta tutkimuksesta. Sen mukaan objektivirheet vähenevät siirryttäessä taitotasolta ylemmälle, mutta kvalitatiivinen analvvsi osoittaa, että alempien tasoien vir- heet ovat laadultaan erilaisia kuin ylemmillä tasoilla. Pirin (2017, s. 89) mukaan oppijat oppivat hallitsemaan objektin yhä kohdekielisemmin taitotason karttuessa (ks. myös Spoelman, 2013), mutta erityisesti aspektuaalisessa totaaliobjektin sijavalinnassa virheitä tapahtuu paljon vielä B2-tasollakin. Näyttääkin siltä, että periaatteessa objektin käsite selviää oppijoille jo kohtuullisen varhain, mutta prosessin edetessä oppijoiden eteen tulee uusia rakenteita, jotka lisäävät objektin sijavalintaan uusia elementtejä ja aiheuttavat myös uudenlaisia virheitä. Esimerkissä (24) on näkyvillä tyypillinen tason A2 virhe: nominatiivin ylikäyttö tapauksessa, jossa pitäisi olla partitiivi (Spoelmanin [2013, s. 212-213] mukaan nominatiivin käyttö onkin tavallista juuri tapauksissa, joissa pitäisi olla partitiiviobjekti). Suurin muutos kehityksessä tapahtuu tasojen B1 ja B2 välillä, jolloin partitiivija totaaliobjektin valinta näyttää selkeytyvän, mutta lauserakenteen monipuolistumisesta kertovat uudet rakenteet aiheuttavat virheitä erityisesti totaaliobjektin sijavalinnassa edelleen B2-tasollakin. Tällaisia ovat esimerkiksi imperatiivi, passiivi ja nesessiiviset rakenteet, jotka vaativat nominatiivimuotoisen objektin genetiivin asemasta (25 ja 26). (Piri, 2017, s. $81-82$.

(24) A2: He kysy mitä ruoka < ruokaa> tänä äiti teki. (VI0421)

(25) B2: Lukitse asunnon <asunto> joka kerta, kun menet pois. (TS0030a)

(26) B2: Lopulta hänen piti hylätä sen <se>. (TS0009i) 
Siitä, johtuvatko objektivirheet intra- vai ekstralingvaalisista syistä, on kahdenlaista mielipidettä. Elo (2000, s. 68) ja Leinonen (2016, s. 78) nojaavat Dulayn ja Burtin (1973, s. 256) näkemykseen ja pitävät objektivirheitä tyypillisinä kehityksellisinä lähtökielestä riippumattomina virheinä. Spoelman (2013, s. 245) tarkentaa, että lähtökielellä on vaikutusta sekä objektivirheiden määrään että laatuun. Vaikka objektin morfosyntaksin ongelmallisuus olisikin intralingvaalinen syy virheisiin, voi virheiden taustalla nähdä myös kieltenvälisen vaikutuksen aiheuttamia syitä. Tästä kertoo esimerkiksi se, että nominatiivimuotoisen objektin liiallinen käyttö yksikön partitiivimuodon sijasta johtuu äidinkielenään lähisukukieltä (viroa) puhuvilla kielenoppijoilla usein lähtökielen negatiivisesta siirtovaikutuksesta, kun taas ei-sukukielisillä oppijoilla (saksa tai hollanti) taustalla on yksinkertaistaminen (Spoelman, 2013, s. 245).
Morfosyntaktisista virheluokista myös adverbiaalin ja verbin kongruenssin hallinnassa tilastollisesti merkitsevää tarkkuuden kehitystä tapahtuu vasta tasojen B1 ja B2 välillä (B1>B2: Z=6,929, $p<0,001$ ).

Kuviosta 2 voidaan havaita seuraavat kehityslinjaa 2 koskevat seikat: 1) oppijoiden virheet lisääntyvät siirryttäessä tasolta $\mathrm{A} 2$ tasolle $B 1$ ja 2) virheet vähenevät tasojen $B 1$ ja $B 2$ välillä $(\mathrm{A} 2<\mathrm{B} 1>\mathrm{B} 2)$.

Virheluokat, joissa on tilastollisesti merkitsevää virheiden lisääntymistä tasojen A2 ja $B 2$ välillä sekä vähenemistä tasojen $B 1$ ja $B 2$ välillä (A2<B1 >B2), ovat ortografiset luokat oikeinkirjoitus ja välimerkit, määritteiden morfosyntaktinen oikeellisuus (edussana oikein, määrite väärässä muodossa, Kaisaa toimisto--), ylimääräiset sanat (Se oli perjantaiilta.) ja fraseologiset virheet (--novellin kieli ei ole hyvin vaikea.) (taulukko 1). Vastaavia tuloksia määritteiden tarkentumisesta on

\section{2. $\mathrm{A} 2<\mathrm{B} 1>\mathrm{B} 2$}

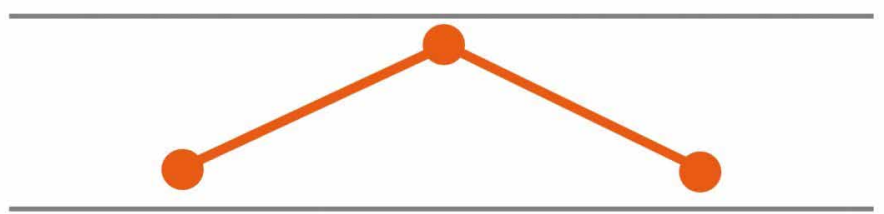

$\begin{array}{lll}\text { A2 } & \text { B1 } & \text { B2 }\end{array}$

Kuvio 2. Virheiden määrän muutos taitotasojen A2, B1 ja B2 välillä: kehityslinja 2. 
saanut myös Mustonen (2015: 248). Tällaista stabilaatiovaiheen sisältävää kehityslinjaa nimitetään U-muotoiseksi kehitykseksi. Ajatus nojaa L2 = L1 -malliin, joka viittaa siihen, että toisen kielen kehitys noudattelee ainakin jossain määrin ensikielen omaksumista, jossa taantumavaihe on yleinen. (Ks. LI = L2 -mallista Ellis, 2008, s. 106-115; U-muotoisesta kehityksestä Ellis, 2008, s. 112; Sjöholm, 1989; Thewissen, 2015, s. 211).

Ortografisten virheiden lisääntymistä selittänee tekstien pidentyminen ja lauserakenteiden monipuolistuminen tason B1 teksteissä. Lisäksi A-tason arvioinnissa ei vielä kiinnitetä isommin huomiota normeihin perustuvien ortografisten seikkojen hallintaan, koska vasta taitotasolla B1 tekstin ylipäätään oletetaan olevan yhtenäinen tekstikokonaisuus, jonka ortografia on niin kehittynyttä, että sitä voi arvioida. (EVK, 2003, s. 96; Tarnanen, 2002, s. 166.) On myös mahdollista, ettei ortografisten virheiden väheneminen kerro pelkästään kielen taitojen kehittymisestä vaan myös normien (iso ja pieni alkukirjain, välimerkit) hallinnan kehittymisestä. Ortografisia virheitä enemmän kielellisissä taidoissa tapahtuvista muutoksista kertoo määritevirheiden lisääntyminen tasojen $\mathrm{A} 2$ ja $\mathrm{B} 1$ välillä $(\mathrm{A} 2<\mathrm{B} 1$ : $\mathrm{Z}=-4,352, p<0,001)$. Alkeistason teksteissä määritteitä ei vielä liiemmin käytetä, mutta tasolle B1 luokitelluissa teksteissä niiden käyttö on jo yleistynyt - vaikkakaan ei vielä vakiintunut (27). Vakiintuminen tapahtuu tämän tutkimuksen valossa vasta tasolla B2, jolloin määritevirheiden määrä vähenee eli tarkkuus kehittyy tilastollisesti merkitsevästi juuri tasojen $\mathrm{B} 1$ ja $\mathrm{B} 2$ välillä $(\mathrm{B} 1>\mathrm{B} 2$ : $\mathrm{Z}=7,962, p<0,001)$ Vastaavia tuloksia on saatu myös Cefling-aineistosta (Mustonen 2015: 132, 183, 195). Myös syntaktisten virheiden pääluokkaan luokiteltuja ylimääräisiä sanoja on usein yhdyslauseissa, joiden määrä alkaa lisääntyä kynnystasolla B1 (28); virheiden määrä vastaavasti vähenee seuraavalle tasolle B2 siirryttäessä $(\mathrm{A} 2<\mathrm{B} 1: \mathrm{Z}=-5,717$, $p<0,001 ; \mathrm{B} 1>\mathrm{B} 2: \mathrm{Z}=2,671,0,001<p>0,05)$. Myös kirjoitetulle suomen kielelle epätyypillistä ja äidinkielen tai suomen puhutun kielen mallin mukaista muodollisen subjektin käyttöä esiintyy paljon tasolla B1 (29).

(27) Ja tärkeä < tärkeät> ihmiset ovat aina monipuolelliset. (KI0010)

(28) Siksi en ole varma, että $<\varnothing>$ voisitteko te lentää minun luoksi. (KI0009)

(29) $\mathrm{Se}<\emptyset>$ on totta, että suuri osa maailman väestöstä kärsii nälkästä. (KI0008)

Fraseologisten virheiden määrä muuttuu vastaavalla tavalla: suurin suhteellinen osuus virheitä on tasolla B1 ja vasta tasojen B1 ja B2 välillä kaikkien fraseologisten virheiden suhteellinen esiintymistiheys pienenee $(\mathrm{A} 2<\mathrm{B} 1$ : $\mathrm{Z}=-8,112, p<0,001 ; \mathrm{B} 1>\mathrm{B} 2: \mathrm{Z}=8,251$, $p<0,001)$. Kielen fraseologisuuden hallinnan ongelmista kertoo kuitenkin se, että tasolla B2 niitä on edelleen enemmän kuin tasolla A2, vaikkakin ero on vain melkein merkitsevä tilastollisesti $(\mathrm{A} 2<\mathrm{B} 2, \mathrm{Z}=-1,996$, $p<0,05)$. Muissa kehityslinjan 2 mukaisissa virheluokissa näin ei tapahdu, vaan tasojen suhteelliset virhemäärät ovat pienempiä tasolla B2 kuin tasolla A2. Fraseologisten virheiden luokan sisällä merkittävin muutos on kollokaatiovirheiksi tulkittavien virheiden suhteellisen osuuden lisääntyminen: kaikista kollokaatiovirheistä 65 prosenttia on tason B2 teksteissä, ja kaikista B2 tason fraseolo- 
gista virheistä liki 60 prosenttia on kollokaatiovirheitä. Kvalitatiivinen analyysi osoittaa, että tavallista on intensiteettisanojen käyttö epätyypillisissä yhteyksissä (30). Kollokaatiovirheiden onkin huomattu olevan yleinen virhetyyppi vielä edistyneilläkin oppijoilla (ks. mm. Nesselhauf, 2005; Thewissen, 2015; erityisesti intensiteettisanojen kollokoinnista, ks. Jantunen, 2015), ja yhtenä syynä virheiden esiintymiseen ylemmilläkin tasoilla voi olla Mustosenkin (2015, s. 287) mainitsema konventionaalisten rakenteiden leksikaalisten elementtien varioiminen.

(30) B2: --- on äitikin laihtunut ja koko aikan ihan surullinen. (VI0385a)

Myös kehityslinjasta 2 voidaan erottaa erityistapaus, jossa tilastollisia muutoksia ei ole havaittavissa molempien tasojen välillä. Tällaisessa tapauksessa muutos on merkitsevä aino-

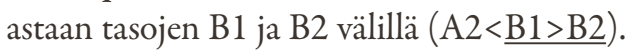
Tällaisia virheluokkia ovat yhdyssana-, vokaa- lisointu-, rektio- ja lausekevirheet (31-34). Tämä vahvistaa kehityslinja 1:n kohdalla tehtyä havaintoa, että tilastollisen merkitsevyyden valossa kielitaidon kehityksessä näyttää tapahtuvan enemmän muutoksia tasojen B1 ja B2 välillä kuin tasojen A2 ja B1 välillä.

(31) yhdyssana: Se oli aivan niinko hotelli-aamupala <hotelliaamupala $>$. (RU0003o)

(32) vokaalisointu: Helsingissa < Helsingissä $>$ (VI0310a)

(33) rektio: tutustuin erilaiset ihmiset $<$ ihmisiin $>(\text { SA0106j) })^{3}$

(34) lauseke: Olen tässä matkassa työssä. (RU0055a)

\footnotetext{
${ }_{3}^{3}$ Virhe koodataan vain edussanaan. Määritteeseen sitä siis ei koodata, koska määrite on muodostettu oikein suhteessa edussanaan.
}

Edellisen tapauksen vastakohta on kehityslinja 3 (kuvio 3), jossa virheet ensin vähenevät tasojen $A 2$ ja B1 välillä ja sen jälkeen lisääntyvät tasojen B1 ja B2 välillä $(\mathrm{A} 2>\mathrm{B} 1<\mathrm{B} 2)$.

Tämä kehityslinja on oppijoilla epätyypillinen, sillä tätä linjaa noudattavia virheluokkia on vain kaksi: verbin muodostaminen sekä tyyli ja rekisteri. Verbin muodostamiseen liittyvät virheet vähenevät tilastollisesti merkitsevästi tasojen $A 2$ ja $B 1$ välillä ( $\mathrm{A} 2>\mathrm{B} 1: \mathrm{Z}=3,536, p<0,001)$ ja lisääntyvät tasojen B1 ja B2 välillä; $(\mathrm{B} 1<\mathrm{B} 2$ : $\mathrm{Z}=0,297$, $p<0,05)$, mutta lisääntyminen ei ole tässä vaiheessa tilastollisesti merkitsevää. Verbien (kuten myös nominien) muodostamisvirheissä kyseessä eivät ole suomen monimutkaiseen morfosyntaksiin liittyvät virheet, vaan ongelma on verbin vartalossa (35). Sen sijaan tyyliin ja rekisteriin liittyvissä virheissä tilastollisesti merkitsevä muutos virheiden lisääntymisessä tapahtuu juuri tasojen $B 1$ ja B2 välillä (A2>B1: $Z=2,525, p<0,05 ; \mathrm{B} 1<\mathrm{B} 2$. $\mathrm{Z}=2,955, p<0,01)(36)$. Luokan virheet ovat tyypillisesti puhekielisyyksiä ja murteellisia 


\section{3. $\mathrm{A} 2>\mathrm{B} 1<\mathrm{B} 2$}

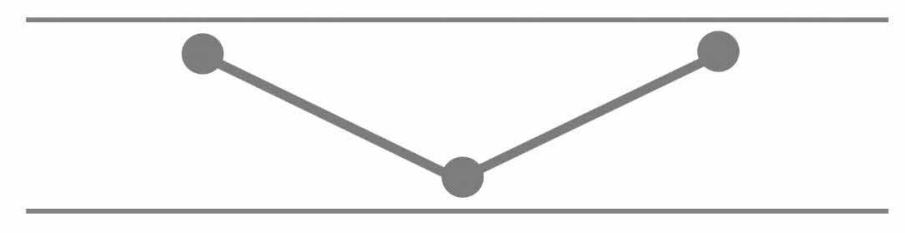

\section{A2 $\quad$ B1 $\quad$ B2}

Kuvio 3. Virheiden määrän muutos taitotasojen A2, B1 ja B2 välillä: kehityslinja 3.

ilmauksia, joita alkaa esiintyä yhä enemmän oppijoiden teksteissä (puhekielisyyksistä oppijantuotoksissa mm. Jantunen, 2008, s. 79-81; 2015, s. 119, 125). Piirteitä esiintyy myös natiivipuhujien kielessä, erityisesti puhutussa ilmaisussa, eikä niitä voi missään nimessä suoraviivaisesti leimata virheiksi. $\mathrm{Ne}$ voitaisiin hyvin nähdä myös kielen progressiota kuvaavaksi piirteeksi, joka kertoisi kielen variaation sekä tvvli- ia tekstitietoisuuden kehittymisestä. Koska virheanalyysin lähtökohtana on kuitenkin normitettu ja standardoitu kirjoitettu yleiskieli, on nämä laskettu virheiksi. Lisäksi aineistomme tekstit ovat opiskelutilanteessa tuotettua kirjoitettua kieltä, jonka tavoitteena yleensä on normien noudattaminen. Tuloksia tulkitessa mahdollinen variaatiotietoisuuden lisääntyminen kehityksen merkkinä tulee kuitenkin ottaa huomioon.

(35) Valitettavasti häntä ei hyvksytä < hyväksytä>. (KI0006g)

(36) Sitten kun mä < minä> tulin kotiin. (RU0059a)

Neljäs kehityslinja (kuvio 4) kuvaa tilannetta, jossa missään kielitaidon edistymistä kuvaavien taitotasojen siirtymävaiheessa ei ole havaittavissa tilastollisesti merkitsevää muutosta $(\mathrm{A} 2 \approx \mathrm{B} 1 \approx \mathrm{B} 2)$.

Tällaisia virheluokkia ovat predikatiivin sija- ja lukuvaihtelu ja morfosyntaktiset sanajärjestykseen, infiniittisiin muotoihin ja lau- setyyppeihin liittyvät virheluokat (taulukko 1). Näille virheluokille on tyypillistä, että niihin kuuluvia seikkoja käsitellään opetuksessa useaan otteeseen. Esimerkiksi predikatiivin sijavaihtelun perusasiat ja monikäyttöiset lausetyypit käsitellään jo opetuksen alkuvaiheessa, kun taas predikatiivin monikkomuodot ja käyttö muun muassa adjektiivien vertai- 


\section{4. $A 2 \approx B 1 \approx B 2$}

Kuvio 4. Virheiden määrän muutos taitotasojen A2, B1 ja B2 välillä: kehityslinja 4.

lumuodoissa sekä erikoislausetyypit tulevat esille vasta myöhemmin. ${ }^{4}$ Tämä näkyy myös seuraavissa esimerkeissä, joissa on tyypillisiä kunkin tason predikatiivin morfosyntaksiin liittyviä virheitä. Tasolla A2 virheitä on myös yksikkömuotojen sijavalinnassa (37),

\footnotetext{
4 Näin siis, mikäli opetus nojaa oppikirjojen järjestykseen, jonka merkitys suomea vieraana kielenä -opetuksessa on ehkä merkittävämpää kuin Suomessa tapahtuvassa kielen oppimisessa. Todellisuudessa oppijat ovat toki voineet tutustua rakenteisiin muussakin järjestyksessä.
}

kun taas tasolla B1 ongelmia aiheuttavat erityisesti monikkomuotojen sijavaihtelut (38). Vastaavia virheitä on paljon vielä myös tasolla B2, mutta siellä mukaan tulee myös adjektiivien taivutusmuotoja, joihin liittyy virheitä sekä yksikössä että monikossa (39). Vaikka virheiden laadussa tapahtuukin muutoksia taitotasoittain, eivät mitkään alemman taitotason virheet kokonaan katoa kielitaidon kehittyessä (40).

(37) A2: Luonnon säästäminen on ekolooginen <ekologista>. (TS0024h)

(38) B1: Petr ja Jan ovat vielä opiskelijat <opiskelijoita>. (TS0026c)

(39) B2: Mutta nykyisin työelämä on työntäyteisempi <työntäyteisempää>. (KI0010bb)

(40) B2: Siks on todella hölmö <hölmöä> tuhlata rahansa siihen. (KI0001k) 
Lausetyyppivirheiksi virheluokituksessa on märritelty tapaukset, joissa epätyypillisyys kiteytyy nimenomaan lausetyypin prototyyppisiin ominaisuuksiin. Luokkana tämä on jokseenkin ongelmallinen, koska usein virheen voisi katsoa olevan myös sanajärjestyksessä tai joissain tapauksissa myös esimerkiksi subjektissa. Lisäksi eksistentiaalilauseissa ongelmia aiheuttaa usein e-subjektin sijavalinta, jonka epätyypilliset muodot on luokiteltu morfosyntaktisiksi subjektivirheiksi. Lausetyyppien virheluokkaan on kuitenkin luettu tapaukset, joissa tekstikonteksti kertoo, että tavoitteena on ollut eksistentiaalinen ilmaus, mutta tuloksena on ollut periaatteessa mahdollinen intransitiivilause (41). Tässä virheluokassa näkynee taitotasoarviointiin perustuva tutkimusasetelma. Alimmille tasoille on luokiteltu tekstit, joissa lausetyyppien kirjo ei ole vielä kovin monipuolinen. Ylemmillä tasoilla lausetyyppejä on käytetty tai ainakin pyritty käyttämään monipuolisemmin $(42,43)$, vaikka eksistentiaalilauseet aiheuttavat sielläkin ongelmia (44). Erilaisten lausetyyppien (normin mukainen tai siitä poikkeava) käyttö on siis todennäköisesti ohjannut tason valikoitumista. Myös lausetyyppeihin läheisesti liittyvien sanajärjestysvirheiden suhteelliset osuudet pysyvät tilastollisesti tarkasteltaessa muuttumattomina ( 45 ja 46).
(41) A2: Historiassa myös ovat kiinnostavat asiat. (TS0020g)
(42) B1: Keskiviikkoiltana pitää minä syödä ravintolaan. (RU0043a)
(43) B2: Suomi tuli autonomiseksi suuriruhtinaskunnaksi. (PU0028a)
(44) B1: Veri ja punainen hilloke ovat myös kaikkialla. (TS0022g)
(45) A2: Minä matkustin kyydissä lautta <lautan kyydissä> Tukholmalta. (RU0043)
(46) B1: Varsinkin pienet lapset Joulusta tykkäävät <tykkäävät joulusta> (TS0014e).

\section{YHTEENVETO JA POHDINTAA}

\subsection{Koonti}

Tarkkuuden kehityksen tarkastelun lähtökohtana on se, millaisia virheitä kullakin taitotasolla tehdään ja millaisia muutoksia virheiden suhteellisissa määrissä tapahtuu. Sen lisäksi tuloksia voidaan tarkastella myös toisesta näkökulmasta: millaisia virheitä taitotasojen arvioijat sallivat kullakin tasolla olevan arvioidessaan tekstit tietylle tasolle.

Aineiston perusteella tasolle A2 arvioiduissa teksteissä on monenlaisia virheitä ja virheiden kokonaismäärä on suuri: suhteutettuna sanemäärään virheiden osuus on jopa 26,8 \%; se tarkoittaa, että keskimäärin joka neljättä sanaa kohden on jonkinlainen virhe (tosin samassa sanassa voi olla useampikin virhe yhtä aikaa). Virheiden suhteellinen kokonaismäärä laskee kuitenkin taitotasojen noustessa roimasti (B1: 23,2 \% > B2: 14,2 $\%)$, mutta kehitys on lineaarista vain harvoissa tapauksissa: 7 tapauksessa kaikista 31:stä (19\%) kehitys jatkuu tasaisesti molemmissa tasojen välisissä vaiheissa $(\mathrm{A} 2>\mathrm{B} 1>\mathrm{B} 2)$. Näin ollen oletuksemme siitä, että virheiden määrä laskisi useassa virheluokassa lineaarisesti, ei aivan toteudu. Edellistä selvemmin ICLFI-aineistossa tarkkuuden kehityksen epälineaarisuutta kuvaa kuitenkin regressio, jota tapahtuu molemmissa tasojen välisissä vaiheissa. Selvästi yleisempää se on tasojen A2 ja $B 1$ välillä: viidessä luokassa (16\%) virheet lisääntyvät, ja regressio on myös tilastollisesti merkitsevää. Tasojen B1 ja B2 välillä regres- 
siota tapahtuu vain yhdessä virheluokassa (tyyli ja rekisteri). Jo aiemmassa suomen kielen oppimista koskevassa tutkimuksessa on havaittu, että ylemmän tason oppijat voivat tuottaa enemmän virheitä kuin alemman tason oppijat muun muassa äidinkielen vaikutuksen vuoksi (Nissilä, 2011: 275) tai siksi, että opittuja ilmauksia ryhdytään varioimaan, mutta tuotos ei ole kohdekielen näkökulmasta odotuksenmukainen (ks. Mustonen, 2015: 184, 287; myös Seilonen, 2013).

Yksinkertaistettuna oppijoiden tarkkuuden kehitys noudattaa stabilaatiota tai regressiota tasojen A2 ja B1 välillä ja progressio keskittyy tasojen B1 ja B2 välille. Kun tätä peilataan oppijoiden kielenoppimiseen, voidaan olettaa, että tasolla B1 kieleen ilmaantuu paljon uusia elementtejä, joita harjoitellessa tehdään paljon virheitä; virheet ovat siis osoitus kielitaidon kehittymisestä. Tasolla B2 käyttö alkaa vakiintua ja virheetkin vähenevät.

Selvimmin ICLFI:n aineistosta nousee esiin se, että tarkkuuden kehityksessä tapahtuu merkittävä harppaus tasojen B1 ja B2 välillä; myös Thewissen (2015, s. 211) pitää juuri tätä kehitysvaihetta eräänlaisena taitekohtana kielenkehityksessä. Tilastollisesti merkitsevää kehitystä tarkkuudessa tapahtuu tässä vaiheessa yli 22 virheluokassa (71 $\%)$. Osassa tapauksista kehitys on lineaarista (virheet ovat edellisessäkin vaiheessa vähentyneet), mutta kaikissa niissä tapauksissa, joissa tarkkuus on kehittynyt tilastollisesti merkitsevästi jo aiemmassa vaiheessa $(\mathrm{A} 2>\mathrm{B} 1)$, vastaava tilastollisesti merkitsevä progressio on jatkunut myös tasojen B1 ja B2 välillä. Sen sijaan seitsemässä tapauksessa tarkkuudessa tapahtuu tilastollisesti merkitsevää progressiota vasta tasojen B1 ja B2 välillä ja aiemmassa siirtymävaiheessa vallitsee stabilaatio. Lisäksi viidessä tapauksessa virheiden suhteelliset osuudet vähenemisen sijasta lisääntyvät tasojen A2 ja B1 välillä. On selvää, että tarkkuuden tutkiminen ei kerro kuin yhden aspektin kielen kehityksen monimuotoisesta ja dynaamisesta kokonaisuudesta, mutta se antaa kiinnostavan lähtökohdan pohtia prosesseja, joista virheiden määrän vaihtelu johtuu. Muun muassa Mustonen (2015, s. $52,283)$ korostaa, että virheiden määrä voi ennakoida nopeaa kehittymistä, koska ennen tarkkuuden lisääntymistä on otettu käyttöön erilaisia mahdollisuuksia tuottaa tavoitemuoto, jota harjoitellaan; virheet ovat siis kehittymisen potentiaali eri taitotasovaiheissa. Shirai (1990, s. 12) muistuttaakin, että virheiden laskemisen sijaan olisi keskityttävä enemmän siihen, mitä lisääntyvät virheet kertovat kielen kehityksen taustalla olevista prosesseista.

Eurooppalaisessa viitekehyksen arviointiasteikossa B1 - ja B2-tasojen kirjallista tuotosta kuvataan selvästi eri tavalla. Tasolla B1 kirjoitukselta edellytetään jo sidosteisuutta, mutta teksti on vielä yksinkertaista ja kuvailevaa, ja aiheet ovat henkilökohtaisia ja tuttuja. Tasolla B2 kirjoitusta kuvataan jo selkeäksi, yksityiskohtaiseksi ja myös tekstilajien kirjo laajenee argumentoiviin esseisiin ja raportteihin eikä kirjoituksessa enää tulisi olla rakenteellisia tai sanastollisia puutteita (EVK, 2003). EVK:ssa annettujen kuvausten rinnalla kyseisten tasojen eroa voitaisiin kuvata myös tarkkuuden merkittävällä progressiolla (ks. myös Thewissen, 2015, s. 211). Yleisen kehityksen lisäksi voidaan esiin nostaa niin kutsuttuja indeksaalisia virheluokkia, joita tämän tutkimuksen valossa ovat erityisesti morfologiset ja morfosyntaktiset virheet, joiden ongelmallisuus kielenoppijoille onkin juuri suomen kielelle tyypillistä (ks. Martin, 1995, s. 186; 2007, s. 77, 79). Näissä pääluokissa virheet vähenevät tilastollisesti merkitsevästi juuri tasojen B1 ja B2 välillä. Merkittävää on kuitenkin se, että virheiden kokonaismäärän kehitys ei vastaa eri virheluokkien kehitystä eikä yhden virheluokan kehitys välttämättä vastaa sen sisällä tapahtuvaa laadullista kehitystä. Esimerkiksi Pirin (2017) tutkimus 
osoitti, että objektivirheiden laatu muuttuu taitotasolta toiselle siirryttäessä. Vastaavia virheluokan sisäisiä laadullisia muutoksia on nähtävissä myös esimerkiksi fraseologisia virheitä tarkasteltaessa: kollokaattivirheet ovat tyypillisiä erityisesti tason B2 teksteissä (ks. myös Mustonen, 2015).

Ainoastaan yhdessä virheluokassa (tyyli ja rekisteri) tasojen B1 ja B2 välillä tapahtuu regressiota. Näitä virheitä sekä kehityslinjan 4 virheitä (predikatiivi, sanajärjestys, ei-finiittiset muodot ja lausetyyppi) voidaan kuvata Thewissenin tapaan (2015, s. 212) positiivisiksi virhetyypeiksi. Vaikka siis teksteissä on nähtävissä yleistä kehitystä, ei sama linja ole nähtävissä näissä virhetyypeissä; virheiden määrä pysyy samana tai jopa hieman lisääntyy. Tämä ei kuitenkaan vaikuta tekstien sijoittamiseen erilaisille taitotasoille, vaan näitä virheitä siis sallitaan edelleen myös tasolla B2. Vastaavia positiivisia virheitä on löydettävissä myös virheluokkien sisältä: esimerkiksi totaaliobjektiin ja e-subjektiin liittyvät sijavalintavirheet ovat yleisiä tasolla B2. Tyypillisesti virheitä tehdään niissä asioissa, joita harjoitellaan, joten tästä voinee päätellä, että totaaliobjektin ja erilaisten lausetyyppien harjoittelu on käynnissä tasolla B2. Yleisemmin tuloksia tarkasteltaessa kiinnostavaa on suhtautuminen morfologisiin ja morfosyntaktisiin seikkoihin, joissa on virheitä selvästi vähiten tasolla B2 (poikkeuksena predikatiivivirheet). Arvioijat siis edellyttävät, että tasolla B2 morfologisen taivutusjärjestelmän ja morfosyntaktisen sijajärjestelmän pitäisi jo olla hallinnassa, mutta syntaksissa (sanajärjestys, lausetyyppi) ja fraseologiassa virheitä sen sijaan sallitaan edelleen.

\subsection{Pohdinta}

Kaiken kaikkiaan potentiaalisten esiintymien analyysin avulla päästään tarkastelemaan kielenoppijoiden tuottamia virheitä entistä tarkemmin: niitä ei suhteuteta tekstimassaan (virkkeiden tai tekstien pituuteen) suoraan, vaan analyysissa huomioidaan kohdat, joissa virhe voisi mahdollisesti esiintyä. Analyysi paljastaa yhtäältä tietyille tasoille tyypilliset virheet, mutta myös taitotasoittaisen kehityksen ja sen, mitkä virhetyypit kuuluvat mihinkin kielenkehityksen siirtymävaiheeseen ja ovat ikään kuin merkkejä kulloisestakin kehitysvaiheesta. Tietyissä virhetyypeissä kahden annotoidun (morfosyntaktinen ja virheannotoitu) aineiston rinnakkainen käyttäminen toimii suomen kielessä erinomaisesti. Morfosyntaktisen annotoinnin avulla potentiaaliset virhepaikat (esim. objektit) saadaan helposti osoitettua, ja se mahdollistaa myös kunkin virheluokan täsmällisemmän analysoimisen (esim. objektiin liittyvät erilaiset virheet [Piri, 2017]). Toisissa virhetyypeissä potentiaalisia virhepaikkoja puolestaan on hyvin vaikea osoittaa. Esimerkiksi fraseologinen virhe voi esiintyä monella tasolla, ja on mahdotonta sanoa, kuinka monta potentiaalista virhettä kirjoittaja voisi tehdä. Tapauksissa, joissa potentiaalisen analyysin edellyttämää vertailukohtaa (nimittäjää) on ollut vaikea määritellä (esim. fraseologiset virheet), onkin tyydytty käyttämään tapauskohtaisesti joko virkkeiden tai saneiden määrää.

Tutkimus poikkeaa aiemmasta kielitaidon kehittymisen tutkimuksesta myös siten, että kielioppijoiden tuottamia virheitä tarkastellaan laajasti; aiemmassa tutkimuksessa on ollut tapana keskittyä tietyntyyppisiin virheisiin tai virheluokkiin, mutta tässä tarkastellaan 32:ta virheluokkaa. Toisaalta tutkimuksessa päästään syventymään virhetyyppien laadullisiin ominaisuuksiin vain joissakin tapauksissa ja silloinkin pintapuolisesti, joten tarkempi laadullinen analyysi jää tuleviin tutkimuksiin. Tutkimusasetelma ei myöskään mahdollista virheiden syiden tai kehityslinjojen tarkkaa analyysia.

Pseudopitkittäistutkimuksella ei päästä 
kiinni todelliseen kielenkehitykseen. Sen sijaan menetelmä kertoo, miten taitotasot poikkeavat toisistaan virheiden määrän ja laadun näkökulmasta, ja tuloksia on pidettävä hypoteeseina siitä, miten kielitaito voi kehittyä tarkkuuden näkökulmasta. Brunni ja Jantunen (2015, s. 389) esittävät tulevaisuuden (korpustutkimuksen) haasteiksi nimenomaan todellisen pitkittäistutkimuksen, jonka avulla päästäisiin kiinni sekä yksilöllisiin että laajamittaisiin kehityslinjoihin. Tässä, kuten aiemmassa Thewisseninkään (2015) tutkimuksessa, ei päästä tarkastelemaan kaikkien EVK:n taitotasojen välisiä kehityslinjoja: Thewissen on tarkastellut taitotasoja B1-C2, käsillä olevassa tutkimuksessa on puolestaan tutkittu tasoja A2-B2. Analyysia rajoittaa ennen kaikkea korpusten koostumus, mikä etenkin suomen osalta riippuu ulkomailla opiskelevien suomen kielen taidosta ja sen arvioinnista. Kontrastiivisen korpusavusteisen virheanalyysin näkökulmasta olisi kuitenkin tarpeellista saada vertailtavaksi samantasoisista aineistoista tehtyjä kehityslinja-analyyseja.

Tarkka korpusavusteinen virheanalyysi on puolestaan kehittänyt laajasta aineistosta tehtävää virheannotointia ja virheanalyysia, ja se mahdollistaa myös yhä uusien analyysien tekemisen samasta virheannotoidusta aineistosta. Menetelmä antaa myös pieniä aineistoja luotettavampaa tietoa virheiden määrästä ja laadusta taitotasoittain. Tekemällä osittain intuitiiviset, vaikkakin holistiset kriteeriviitteiset taitotasoarvioinnit entistä läpinäkyvimmiksi päästään paremmin selvittämään myös arvioinnin validiutta. (Hyödyistä ks. myös Thewissen, 2015, s. 269-270.)

Tämä tutkimus ei ota kantaa oppijan äidinkielen tai esimerkiksi iän vaikutukseen kielitaidon ja tarkkuuden kehittymisessä. Useissa tutkimuksissa on todettu, että äidinkieli voi vaikuttaa monien kielenpiirteiden oppimiseen, ja kehittyminen voi olla erilaista äidinkielestä riippuen (suomen oppimisesta mm. Kaivapalu, 2005; Nissilä, 2011; Siivelt \& Mustonen, 2013, s. 341-370). Lisäksi kehitykseen voivat vaikuttaa myös oppijoiden ikä (Mustonen, 2015; Seilonen, 2013) ja tuotokseen yleensä oppimiskonteksti (Jantunen, 2015, s. 105-136). Jatkotutkimuksessa olisikin tarpeen selvittää, miten erilaiset taustamuuttujat vaikuttavat kehitykseen, yhdessä tai erikseen.

\section{LÄHTEET}

Abe, M. \& Tono, Y. (2005). Variations in L2 spoken and written English: Investigating patterns of grammatical errors across proficiency levels. The corpus linguistics

conference series 1.1. Corpus Linguistics 2005. Haettu 5.4.2019 osoitteesta https://www. birmingham.ac.uk/research/activity/corpus/ publications/conference-archives/2005-confe-journal.aspx.

Brunni, S. \& Jantunen, J. H. (2015). Learner language. Teoksessa M. Bigelow \& J. EnnserKananen (toim.), The Routledge handbook of educational linguistics, (s. 383-394). New York: Routledge.

Brunni, S., Lehto, L-M., Jantunen, J. H. \& Airaksinen, V. (2015). How to annotate morphologically rich learner language. Principles, problems and solutions. Teoksessa A-K. Helland Gujord, S. Nacey \& S. Ragnhildstveit (toim.), Learner corpus research: LCR2013 conference proceedings. Bergen language and linguistics studies, 6, (s. 133-152). Bergen: University of Bergen. Haettu 7.5.2019 osoitteesta https://bells.uib. no/index.php/bells/article/view/812/752.

CECL (2018). Learner corpora around the world. Louvain-la-Neuve: Centre for English corpus linguistics, UCL. Haettu 11.5.2018 osoitteesta https://uclouvain.be/en/research-institutes/ $\mathrm{ilc/cecl/learner-corpora-around-the-world.}$ html.

Corder, S. P. (1967). The significance of learner's errors. International Review of Applied Linguistics, 5, 161-170.

Crookes, G. (1989). Planning and interlanguage variability. Studies in Second Language Acquisition, 11, 367-383. 
Dagneaux, E., Dennes, S. \& Granger, S. (1998). Computer-aided error analysis. System, 26, 163-174.

De Bot, K., Lowie, W. M. \& Verspoor, M. H. (2007). A dynamic systems theory approach to second language acquisition. Bilingualism: Language and cognition, 10, 7-21.

Dufva, H., Aro M. \& Suni, M. (2014). Language learning as appropriation: how

linguistic resources are recycled and regenerated. Teoksessa P. Lintunen,

M. S. Peltola \& M.-L. Varila (toim.), AFinLAe. Soveltavan kielitieteen tutkimuksia, 6, (s. 20-31). Haettu 7.5.2019 osoitteesta https:// journal.fi/afinla/article/view/46278.

Dulay, H. \& Burt, M. (1973). Should we teach children syntax? Language Learning, 23, 95123.

Ellis, N. (2015). Implicit AND explicit learning: Their dynamic interface and complexity. Teoksessa P. Rebuschat (toim.), Implicit and explicit learning of languages, (s. 3-24). Amsterdam: John Benjamins.

Ellis, R. (2008). The study of second language acquisition (2. painos). Oxford: Oxford University Press.

Ellis, R. \& Barkhuizen, G. (2005). Analyzing learner language. Oxford: Oxford University Press.

Ellis, R. \& Yuan, F. (2005). The effects of careful within-task planning on oral and written task performance. Teoksessa R. Ellis (toim.), Planning and task performance in a second language, (s. 167-192). Amsterdam: John Benjamins.

Elo, E. (2000). Suomenoppijan syntaktisia ongelmia suomi toisena ja vieraana kielenä ylioppilaskokeessa. Teoksessa S. Martin \& H. Sulkala (toim.), Tutkielmia oppijankielestä. Suomen ja saamen ja logopedian laitoksen julkaisuja, 17, (s. 54-72). Oulu: Suomen ja saamen kielen ja logopedian laitos.

Eskildsen, S. W. (2008). Constructing another language. Usage-based linguistics in second language acquisition. Applied Linguistics, 30, 335-357.

Euroopan neuvosto (2001). Common European framework of reference for languages: Learning, teaching, assessment. Cambridge: Cambridge University Press.

$\mathrm{EVK}=$ Eurooppalainen viitekehys: kielten oppimisen, opettamisen ja arvioinnin yhteinen eurooppalainen viitekehys (2003). Helsinki: WSOY.
Gass, S. M. \& Selinker, L. (2008). Second language acquisition (4. painos). New York: Routledge.

Gehring, S. \& Heinzmann, S. (2010, 2012). Suomen mestari 1-2. Helsinki: Finn Lectura.

Gehring, S., Heinzmann, S., Päivärinne, S. \& Udd, T. (2013, 2016). Suomen mestari 3-4. Helsinki: Finn Lectura.

Granger, S. (2002). A bird's-eye view of learner corpus research. Teoksessa S. Granger, J. Hung \& S. Petch-Tyson (toim.), Computer learner corpora, second language acquisition and foreign language teaching, (s. 3-33). Amsterdam: John Benjamins.

Granger, S. (2003). Error-tagged learner corpora and CALL: A promising synergy. CALICO Journal, 20, 465-80.

Granger, S. (2015). Contrastive interlanguage analysis: A reappraisal. International Journal of Learner Corpus Research, 1, 7-24.

Granger, S., Dagneaux, E., Meunier, F., \& Paquot, M. (2009). The international corpus of learner English. Version 2. Käsikirja ja CD-ROM. Louvain-la-Neuve: Presses Universitaires de Louvain.

Hammarberg, B., Håkansson, G. \& Martin, M. (1999). Cognitive and functional aspects of second language development. Teoksessa P. Pietilä \& O.-P. Salo (toim.), Multiple languages - multiple perpectives. AfinLan julkaisuja, 57, (s. 55-82). Jyväskylä: Suomen soveltavan kielentutkimuksen yhdistys. Haettu 5.4.2019 osoitteesta http://elektra.helsinki.fi/se/a/07810318/1999/57/cognitiv.pdf.

Hasko, V. (2013). Capturing the dynamics of second language development via learner corpus research: A very long engagement. The Modern Language Journal, 97, 1-10.

Housen, A. \& Kuiken, F. (2009). Complexity, accuracy, and fluency in second language acquisition. Applied Linguistics, 30, 461-473. Haettu 5.4.2019 osoitteesta https://academic. oup.com/applij/article-abstract/30/4/461/2.

Hulstijn, J. H., Young, R. F., Ortega, L., Bigelow, M., DeKeyser, R., Ellis, N. C.,

Lantolf, J. P., Mackey, A., \& Talmy, S. (2014). Bridging the gap: Cognitive

and social approaches to research in second language learning and

teaching. Studies in Second Language Acquisition, 36, 361-421.

Hunt, T. (1965). Grammatical structures written 
at three grade levels. NCTE research report No. 3. Haettu 5.4.2019 osoitteesta https://files.eric. ed.gov/fulltext/ED113735.pdf.

Huttu-Hiltunen, M. (2017).Joka-, mikä-ja kukarelatiivikonstruktioiden virheet virolaisten suomenoppijoiden kirjoitelmissa. Suomen kielen pro gradu -tutkielma. Oulun yliopisto.

ICLFI:n virheannotointimanuaali. (2014). Haettu 5.4.2019 osoitteesta https://www.oulu.fi/ suomitoisenakielena/node/16078.

Izumi, E., Uchimoto, K. \& Isahara, H. (2005). Error annotation for corpus of Japanese learner English. Teoksessa K. Paik, F. Bond \& S. Oepen (toim.), Proceedings of the sixth international workshop on linguistically interpreted corpora (LINC-2005), (s. 71-80). Haettu 7.5.2019 osoitteesta http://acl-arc.comp.nus.edu.sg/archives/acl-arc-090501d3/data/pdf/anthologyPDF/I/I05/I05-6009.pdf.

James, C. (1998). Errors in language learning and use. Exploring error analysis. London: Longman.

Jantunen, J. H. (2008). Haasteita oppijankielen korpusanalyysille: oppijankielen universaalit. Teoksessa P. Eslon (toim.), Õppijakeele analüüs: võimalused, probleemid, vajadused. Tallinna ülikooli eesti filoloogia osakonna edetised, 10, (s. 67-92). Tallinn: TLÜ Kirjastus.

Jantunen, J. H. (2011). Kansainvälinen oppijansuomen korpus (ICLFI): typologia, taustamuuttujat ja annotointi. Teoksessa A. Kaivapalu, J., Laakso, P. Muikku-Werner \& M.-M. Sepper (toim.), Lähivõrdlusi. Lähivertailuja, 21, (s. 86-105). Tallinna: Eesti Rakenduslingvistika Ühing.

Jantunen, J. H. (2015). Oppimiskontekstin vaikutus oppijanpragmatiikkaan: astemääritteet leksikaalisina nallekarhuina. Teoksessa A. Kaivapalu, J. Laakso, M.-M. Sepper, K. Siitonen \& K. Õim. (toim.), Lähivõrdlusi. Lähivertailuja, 25, (s. 105-136). Tallinna: Eesti Rakenduslingvistika Ühing.

Jantunen, J. H., Brunni, S., Lehto, L.-M. \& Airaksinen, V. (2014). Oppijankieliaineistojen annotointi. Esimerkkinä ICLFI:n annotoinnin prosessit, ongelmat ja ratkaisut. Teoksessa M. Mutta, P. Lintunen, I. Ivaska \& P. Peltonen (toim.), AFinLA-e: Soveltavan kielitieteen tutkimuksia, 7, (s. 60-80). Jyväskylä: Suomen soveltavan kielentutkimuksen yhdistys.
Jantunen, J. H., Brunni, S. \& Oulun yliopisto, suomen kielen oppiaine (2013). Kansainvälinen oppijansuomen korpus [tekstikorpus]. Kielipankki. Haettu 5.4.2019 osoitteesta http:// urn.fi/urn:nbn:fi:lb-20140730163.

Jantunen, J. H. \& Pirkola, S. (2015). Oppijansuomen sähköiset tutkimusaineistot. Nykytilanne. Virittäjä, 119, 88-103.

Jarvis, S. \& Pavlenko, A. (2008). Crosslinguistic influence in language and cognition. New York: Routledge.

Kaivapalu, A. (2005). Lähdekieli kielenoppimisen apuna. Jyväskylä studies in humanities 44. Jyväskylä: Jyväskylän yliopisto.

Kajander, M. (2013). Suomen eksistentiaalilause toisen kielen oppimisen polulla. Jyväskylä: Jyväskylän yliopisto.

Kenttälä, M. (2006, 2012). Suomi sujuvaksi 1-2. Helsinki: Gaudeamus.

Krashen, S. (1982). Principles and practice in second language acquisition. London: Pergamon.

Lado, R. (1957). Linguistics across cultures: Applied linguistics for language teachers. Ann Arbor: University of Michigan Press.

Larsen-Freeman, D. (2007). Reflecting on the cognitive-social debate in second language acquisition. The Modern Language Journal, 91, 773-787.

Larsen-Freeman, D. (2013). Chaos/complexity theory for second language acquisition. Teoksessa C. A. Chapelle (toim.), The encyclopedia of applied linguistics, (s. 60-80). Chichester: Blackwell.

Leinonen, Rikupekka. (2016). "Ja mum mielestä siellä jopa voi vuokrata vene": nominaalisten lauseenjäsenten epätyypillisyyksiä Suomen täydelliset venäläisnaiset-tv-sarjassa. Suomen kielen pro gradu -tutkielma. Oulun yliopisto.

Long, M. I. (2003). Stabilization and fossilization in interlanguage development. Teoksessa C. Doughty \& M. Long (toim.), The Handbook of second language acquisition, (s. 487-536). Malden: Blackwell.

Long, M. I. \& De Sato, C. (1984). Methodological issues in interlanguage studies; an interactionist perspective. Teoksessa A. Davies, C. Criper \& A. P. R. Howart (toim.), Interlanguage, (s. 253279). Edinburgh: Edinburgh University Press.

Martin, M. (1995). The map and the rope. Finnish nominal inflection as a learning target. Jyväskylä: 
Jyväskylän yliopisto.

Martin, M. (2007). A square peg into a round hole? Fifteen years of Finnish as a second language research. Nordand - Nordisk tidsskrift for andrespråksforskning 1, 63-86.

Martin, M., Mustonen, S., Reiman, N. \& Seilonen, M. (2010). On becoming an independent user. Teoksessa I. Bartning, M. Martin \& I. Vedder (toim.), Communicative proficiency and linguistic development. EuroSLA Monograph Series 1, (s. 57-80). EUROSLA. Haettu 5.4.2019 osoitteesta http://eurosla.org/monographs/ EM01/57-80Martin et al.pdf.

Martin, S. (2002). Objektin sijanvalinta italialaisten suomenoppijoiden kirjoitelmissa. Teoksessa S. Rantatalo \& H. Sulkala (toim.), Tutkielmia oppijankielestä II. Oulun yliopiston suomen ja saamen kielen ja logopedian laitoksen julkaisuja 21, (s. 109-130). Oulu: Suomen ja saamen kielen ja logopedian laitos.

Milton, J. \& Chowdhury, N. (1994). Tagging the interlanguage of Chinese learners of English. Teoksessa L. Flowerdew \& A. Tong (toim.), Entering text, (s. 127-143). Hong Kong: The Hong Kong University of science and technology.

Muikku-Werner, P. (2002). Te kävitte suomessa? Virolaisten ja saksalaisten oppijansuomen syntaksia. Teoksessa S. Rantatalo \& H. Sulkala (toim.), Tutkielmia oppijankielestä II. Suomen ja saamen ja logopedian laitoksen julkaisuja 17, (s. 7-47). Oulu: Suomen ja saamen kielen ja logopedian laitos.

Mustonen, S. (2015). Käytössä kehittyvä kieli. Paikat ja tilat suomi toisena kielenä-oppijoiden teksteissä. Jyväskylä: Jyväskylän yliopisto.

Nesselhauf, N. (2005). Collocations in a learner corpus. Studies in corpus linguistics 14. Amsterdam: John Benjamins.

Nissilä, L. (2011). Viron kielen vaikutus suomen kielen verbien ja niiden rektioiden oppimiseen. Acta Universitatis Ouluensis B, 99. Oulu: Oulun yliopisto.

Odlin, T. (1989). Language transfer. Cross-linguistic influence in language learning. Cambridge: Cambridge University Press.

Pienemann, M. (1998). Language processing and second language development: processability theory. Amsterdam: John Benjamins.

Piri, O.-J. (2017). Morfosyntaktiset objektivirheet oppijansuomessa. Korpuspohjainen kuvaus suo- menoppijoiden kielitaidon tarkkuuden kehityksestä. Suomen kielen pro gradu -tutkielma. Oulun yliopisto.

Preston, D. (1996). Variationist perspectives on second language acquisition. Teoksessa R. J. Bayley \& D. R. Preston (toim.), Second language acquisition and linguistic variation, (s. 1-45). Amsterdam: John Benjamins.

Richards, J. C. (1971). A non-nontrastive approach to Error Analysis. English Language Teaching, 25, 204-219.

Seilonen, M. (2013). Epäsuora henkilöön viittaaminen oppijansuomessa. Jyväskylä: Jyväskylän yliopisto.

Selinker, L. (1972). Interlanguage. International Review of Applied Linguistics in Language Teaching, 10, 209-231.

Shirai, Y. (1990). U-shaped behavior in L2 acquisition. Teoksessa H. Burmeister \& P. L. Rounds (toim.), Variability in second language acquisition: Proceedings of the tenth meeting of the second language research forum, vol. 2 (s. 685-700). Eugene, OR: Department of Linguistics, University of Oregon.

Siivelt, K. \& Mustonen, S. (2013). Lähdekielen vaikutus ja kielitaitotasot: paikallissijojen kehitys oppijansuomessa. Teoksessa A. Kaivapalu, P. Muikku-Werner, J. Laakso, K. Óim \&, M.M. Sepper (toim.) Lähivõrdlusi. Lähivertailuja, 23, (s. 341-370). Tallinna: Eesti Rakenduslingvistika Ühing.

Sjöholm, K. (1989). Is the pattern of L2-learning U-shaped? Teoksessa A. Nuopponen \& R. Palmberg (toim.), Special Languages and Second Languages: Methodology and Research. AFinLAn julkaisuja 47, (s. 221-231). Vaasa: Suomen soveltavan kieliteen yhdistys. Haettu 5.4.2019 osoitteesta https://journal.fi/afinlavk/article/view/57780.

Skehan, P. \& Foster, P. (2008). Complexity, accuracy, fluency and lexis in task-based performance: a meta-analysis of the Ealing research. Teoksessa S. Van Daele, S. Housen, F. Kuiken, M. Pierrard, \& I. Vedder (toim.), Complexity, accuracy, and fluency in second language use, learning, and teaching. Contactforum, (s. 207226). Brussel: Koninklijke Vlaamse Academie van België voor Wetenschappen en Kunsten.

Spoelman, M. (2013). Prior linguistic knowledge matters: the use of the partitive case in Finnish learner language. University of Oulu. 
Sprinthall, R. C. (2011). Basic statistical analysis (9. painos). Pearson Education. Boston, MA: Ally \& Bacon.

Tarnanen, M. (2002). Arvioija valokeilassa. Suomi toisena kielenä-kirjoittamisen arviointia. Jyväskylä: Jyväskylän yliopisto.

Tarone, E. (1983). On the variability of interlanguage systems. Applied Linguistics, 4, 143-163.

Thewissen, J. (2015). Accuracy across proficiency levels: A learner corpus approach. Louvain-laNeuve: Presses universitaires de Louvain.

Tikkanen, L. \& Tähtinen, N. (2017,2018). Ahaa! 1-2, Suomen kielen oppikirja aikuisille. Helsinki: Finn Lectura.

Van Els, T., Bongaerts, T., Extra, G., Van Os, C. \& Jansen-van Dieten, A.-M. (1984). Applied linguistics and the learning and teaching of foreign languages. London: Edward Arnold.
Verspoor, M., Schmidt, M. S. \& Xu, X. (2012). A dynamic usage-based perspective on L2 writing. Journal of Second Language Writing, 21, 239-263.

White, L. (2003) From Start to Finnish. A short course in Finnish. Helsinki: Finn Lectura.

Wulff, S. \& Gries, S. Th. (2011). Corpus-driven methods for assessing accuracy in learner production. Teoksessa P. Robinson (toim.), Second language task complexity: researching the cognition hypothesis of language learning and performance, (s. 61-88). Amsterdam: John Benjamins.

Yuan, F. \& Ellis, R. (2003). The effects of pretask planning and on-line planning on fluency, complexity and accuracy in L2 monologic oral production. Applied Linguistics, 24, 1-27. 


\section{CORPUS-AIDED ERROR ANALYSIS OF THE DEVELOPMENT OF ACCURACY BETWEEN CEFR LEVELS A2 AND B2}

Sisko Brunni, University of Oulu

Jarmo Jantunen, University of Jyväskylä

Valtteri Skantsi, University of Oulu

In this article, the development of an individual's language proficiency, based here on the language levels of Common European Framework for Reference, is examined with the help of Potential Occasion Analysis (Thewissen, 2015). The development is analyzed from the viewpoint of accuracy, and it is measured by the amount of forms that differ from the conventions of form and usage in the target language. The research represents corpus-aided error analysis (Dagneaux et al., 1998), and it is based on the statistical testing of the amount of errors seen in the nine categories of errors found in the reference levels of language proficiency. The research material consists of the International Corpus of Learner Finnish (ICLFI). The analysis shows that the most remarkable progress happens between levels B1 and B2. In addition, in the progress between levels $\mathrm{A} 2$ and $\mathrm{B} 1$, there is regression in the form of, for example, errors in adjuncts and phraseology as well as stabilization, which can especially be seen in morphosyntactic and syntactic errors. However, the change between B1 and B2 is so distinct that the increase in morphosyntactic and syntactic accuracy could be made one of the defining aspects of level B2. Earlier studies have indicated level B1 as a distinct culmination point in the development of language (see e.g. Kajander, 2013, p. 93-95; Seilonen, 2013, p. 59-61; Thewissen, 2015), and on the basis of this study's results, this is also the case for the development of language accuracy.

Keywords: accuracy, corpus-aided error analysis, development of language proficiency, potential occasion analysis 